\title{
INTERPRETATION OF FUNDAMENTAL RIGHTS IN POLAND
}

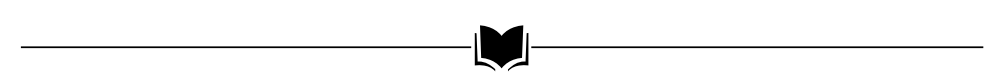

PIOTR MOSTOWIK

\section{The Polish Constitutional Tribunal: Introductory Remarks}

\subsection{The Constitutional Tribunal and judges}

The first constitution (in the modern meaning) in Poland was issued on 3 May 1791, the second oldest such written document in the world. ${ }^{1}$ It was adopted by the Polish-Lithuanian Commonwealth to ensure greater freedom and political equality on its territory and introduce a constitutional monarchical system. It was also the symbol of Poland's national identity after independence was lost (division and occupation by the Austrian, German, and Russian empires until 1918).

The next constitutions were adopted in independent Poland in the XXth century on 20 February 1919 (called the 'small' one), 17 March 1921 (called the 'March' one, with a division of powers modelled on the French constitution of 1875), and 23 April 1935 (called the 'April' one, delegating greater competence to the President). After World War II, during the period of the 'Peoples' Republic of Poland', the next constitutions were adopted on 19 February 1947 (called the 'small' one) and on 22 July

1 Translation into English by F. Bukaty (with foreword by A. Grześkowiak-Krwawicz). It is available at: http://agad.gov.pl/wp-content/uploads/2018/12/Konstytucja-3-maja_Eng-v4.pdf. See: Müsig, 2015, pp. 75-93. See also other constitutional materials published online by Polish History Museum in Warsaw and at: www.polishfreedom.pl/en/document/constitution-of-the-3rd-of-may-1791-thegovernment-statute.

Piotr Mostowik (2021) Interpretation of Fundamental Rights in Poland. In: Zoltán J. Tóth (ed.) Constitutional Reasoning and Constitutional Interpretation, pp. 401-467. Budapest-Miskolc, Ferenc Mádl Institute of Comparative Law-Central European Academic Publishing. 
1952 (modelled on the Soviet constitution of 1936). After the fundamental political changes in the years 1988-89, the last one was modified into the 'Constitution of the Polish Republic' (31 December 1989), followed by the act of 17 October 1992 (again called the 'small constitution'). Finally, on 2 April 1997, the current Constitution of the Republic of Poland was adopted by the National Assembly and accepted in a referendum. ${ }^{2}$ It provides for the position of a Constitutional Tribunal in the Polish political and legal system.

The establishment of the Constitutional Tribunal in Poland was the content of proposals by the National Congress of the 'Solidarność' ('Solidarity') movement in 1981. In the fall of that year, the works of experts on its establishment (and the Tribunal of State) were undertaken, and on 26 March 1982 an amendment provided for the introduction of these two institutions. However, this body was not able to start functioning within a few months. The Act on the Constitutional Tribunal was passed on 29 April 1985 that stated the limited competences of this body. After the political breakthrough in 1989, the need to strengthen its position was widely accepted and legally introduced. Still, the Sejm's competence was-by a qualified majority-to reject the Tribunal's rulings on the unconstitutionality of a statute. In the last decades the Tribunal has created an extensive jurisprudence and gained considerable authority among the political elite, as well as representatives of legal doctrine. In particular, such constitutional clauses as the rule of law and the principle of equality have been developed, and many gaps and doubtful areas have been filled in the concept of the democratic rule of law.

As far as the composition and organisation is concerned-in light of Arts. 190(5) and 194-196-the Polish Constitutional Tribunal is composed of 15 judges, who should be persons distinguished by their knowledge of the law. No person may be chosen for more than one term of office. ${ }^{3}$ Judges are chosen individually by the Sejm for a term of office of nine years. Judgments of the Tribunal shall be made by a majority of votes.

The general rule is that in the exercise of their office the judges shall be independent and 'subject only to the Constitution' (in the sense that only it binds them legally). In order that this rule be fulfilled, judges shall be provided with appropriate conditions for work and granted remuneration consistent with the dignity of the office and the scope of their duties. During their term of office, they shall not belong to a political party or a trade union or perform public activities incompatible with the principles of the independence of the courts and judges. ${ }^{4}$

2 The Constitution of the Republic of Poland, as adopted by the National Assembly on 2 April 1997, officially published in 'Dziennik Ustaw' 1997 no. 78, item 483; hereinafter 'the Constitution'.

The translation into English published by Parliamentary Services that is the terminological basis for this paper. It is available at: https://www.sejm.gov.pl/prawo/konst/angielski/konse.htm.

3 The President and Vice-President shall be appointed by the President of the Republic from candidates proposed by the General Assembly of the Judges of the Tribunal.

4 Moreover, judges shall not be held criminally responsible or deprived of liberty without prior consent granted by the Tribunal. A judge shall be neither detained nor arrested, except for cases when he has been apprehended in the commission of an offense and in which his detention is necessary for securing the proper course of proceedings. The President of Tribunal shall be notified forthwith of any such detention and may order an immediate release of the person detained. 


\subsection{Powers of the Constitutional Court}

As far as the system of division of power and constitutional function of the Tribunal is concerned, at present under Art. 10 (2) of the Polish Constitution of 1997, legislative power shall be vested in the Sejm and the Senate (i.e. the chambers of parliament), executive power shall be vested in the President and the Council of Ministers, and judicial power shall be vested in courts and tribunals, including the Constitutional Tribunal. ${ }^{5}$ They shall, according to Art. 173, constitute a separate power and shall be independent of the other branches of power.

Thecharacteristic powers of the discussed constitutional court are ex-ante norm control, such that constitutional complaints and political matters (e.g. banning political parties). Arts. 188-189 and 191 of the Constitution state the most important competences of the Constitutional Tribunal. It shall adjudicate regarding the following matters:

- the conformity of statutes and international agreements to the Constitution;

- the conformity of a statute with ratified international agreements the ratification of which required prior consent expressed in the statute

- the conformity of legal provisions issued by central State organs to the Constitution, ratified international agreements, and statutes;

- the conformity to the Constitution of the purposes or activities of political parties;

- complaints concerning constitutional infringements; ${ }^{6}$ and shall settle

- disputes over authority between central constitutional organs of the State. ${ }^{7}$

\subsection{General characteristics of the procedure}

It should be added that the following persons may apply to the Constitutional Tribunal regarding the abovementioned matters: 1) the President of the Republic, the Marshal of the Sejm, the Marshal of the Senate, the Prime Minister, 50 deputies of the Sejm, 30 senators, the First President of the Supreme Court, the President of the Chief Administrative Court, the Public Prosecutor-General, the President of the Supreme Chamber of Control, and the Commissioner for Citizens' Rights; 2) the National Council of the Judiciary (to a limited extent); and-regarding matters relevant

5 See Garlicki, 2007, pp. 44-68. Author concludes that 'thus, for the constitutional court, dialogue and persuasion seem to be more effective than open conflicts and confrontations with other jurisdictions' (p. 68).

6 Art. 79 states, that everyone whose constitutional freedoms or rights have been infringed, shall have the right to appeal to the Constitutional Tribunal for its judgment on the conformity to the Constitution of a statute or another normative act upon which basis a court or organ of public administration has made a final decision on his freedoms or rights or on his obligations specified in the Constitution.

7 The following persons may, in light of Art. 192, make application to the Constitutional Tribunal in respect of this matters: the President of the Republic, the Marshal of the Sejm, the Marshal of the Senate, the Prime Minister, the First President of the Supreme Court, the President of the Chief Administrative Court and the President of the Supreme Chamber of Control. 
to the scope of their activity-3) the constitutive organs of units of local self-government; 4) the national organs of trade unions as well as the national authorities of employers' organizations and occupational organizations; 5) churches and religious organizations; and 6) bodies whose constitutional freedoms or rights have been infringed (to a limited extent). Additionally, any court may refer a question as to the conformity of a normative act to the Constitution, ratified international agreements, or statute, if the answer to such question of law will determine an issue currently before this court. This last situation is quite common in practice. ${ }^{8}$ According to Art. 193, any court may refer a question of law to the Constitutional Tribunal as to the conformity of a normative act (including statutes and ratified international agreements) to the Constitution if the answer to such question of law will determine an issue currently before this court.

The other provisions of this chapter, as well as rules stipulated in other chapters complement these competences. Under Art. 122 (3) the President may, before signing a bill, refer it to the Constitutional Tribunal for adjudication. The President shall then not refuse to sign a bill that has been judged as conforming to the Constitution. ${ }^{9}$ According to Art. 133 (2), before ratifying an international agreement the President may also refer it to the Tribunal with a request to adjudicate upon its conformity to the Constitution. The latter competence may also create interesting issues of interpretation regarding the interface between the Constitution and international law, as well as the application of the judgments of the ECtHR and the CJEU by the Tribunal.

The Constitution of 1997 also covers the effects of the Tribunal's rulings, as well the details of the composition and basis of operation of the constitutional court. Art. 190 stipulates that judgments shall be of universally binding application and shall be final. They generally shall be immediately published in the official publication in which the original normative act was promulgated. ${ }^{10}$ The judgment shall take effect from the day of its publication; however, the Tribunal may specify another date for the end of the binding force of a normative act. ${ }^{11}$ What is important for practitioners

8 Recent activities and basic information and reports in English are available at: https://trybunal.gov. $\mathrm{pl} / \mathrm{en}$.

9 Additionally, under Art. 131, when President is temporarily unable to discharge the duties of his office, he shall communicate this fact to the Marshal of the Sejm (a function comparable to speaker), who shall temporarily assume his duties. If President is not in a position to inform the Marshal, then the Constitutional Tribunal shall, on request of the Marshal, determine whether or not there exists an impediment to the exercise of the office by the President. If the Constitutional Tribunal so finds, it shall require the Marshal to temporarily perform the duties of the President. This provision was applied in practice after the tragic death of President Lech Kaczyński near Smolensk on 10 April 2010. This time Marshal of the Sejm Bronisław Komorowski temporarily took over the duties (and then was chosen in the general election for years 2010-15).

10 Mostly in 'Dziennik Ustaw'. If a normative act has not been promulgated, then the judgment shall be published in the second official gazette of the Republic of Poland: 'Monitor Polski'.

11 Such time period may not exceed 18 months in relation to a statute or 12 months in relation to any other normative act. Where a judgment has financial consequences not provided for in the Budget, the Constitutional Tribunal shall specify date for the end of the binding force of the normative act concerned, after seeking the opinion of the Council of Ministers. 
is that the judgment stipulating non-conformity to the Constitution (or to an international agreement or statute) of a normative act on the basis of which a legally effective judgment of a court (or a final administrative decision or settlement of other matters) was issued shall be a basis for re-opening proceedings (or for quashing the decision or other settlement) in a manner and upon principles specified in provisions applicable to the given proceedings.

Further details of organization and of proceedings before the Tribunal are specified by statutes adopted by parliament in ordinary legislative procedure. In the last years, especially in connection with a legal and political dispute in the years 2015-2016 (focused on the procedure of appointment of new judges ${ }^{12}$ ), the statute law has been amended several times, which has in practice caused problems in determining the current content of the law and intertemporal issues. From the perspective of the legal status in 2021 and the current proceedings before the tribunal, the detailed provisions of following statutes (supplementary to the abovementioned constitutional principles) apply:

- the Act of 30.11.2016 on the Organisation of the Constitutional Tribunal and the Mode of Proceedings Before the Constitutional Tribunal, ${ }^{13}$ and

- the Act of 30.11.2016 on the Status of the Judges of the Constitutional Tribunal. ${ }^{14}$

\section{Reasoning of the Polish Constitutional Tribunal and relevant jurisprudence of the ECtHR and CJEU}

\subsection{Study approach and choice of the decisions examined, with special attention to external systemic (comparative) interpretation referring to international case law}

This section covers the principal part of this study, which is the interpretation of the constitutional principles (not statutory ones)-i.e. applicable constitutional provisions and fundamental rights. The main content of this part is focused also on

12 The different legal approaches and interpretation are presented by: Team of Experts, 2016; European Commission for Democracy through Law, 2016.

See: Kustra, 2016, pp. 343-366; Radziewicz, 2017, pp. 23-40; Chmielarz-Grochal, Sułkowski, 2018, pp. 93-99; Szmulik, Szymanek, 2020, pp. 261-275.

See also the detailed presentation of the period from June 2015 to March 2016: Tuleja (ed.), 2017.

13 Officially Published in 'Dziennik Ustaw' of 19.12.2016, item 2072. Translation into English, prepared by Tribunal's services, is available at: https://trybunal.gov.pl/en/about-the-tribunal/legalbasis/the-constitutional-tribunal-act.

14 Officially published in 'Dziennik Ustaw' of 19.12.2016, item 2073. Translation into English, prepared by Tribunal's services, is available at: https://trybunal.gov.pl/en/about-the-tribunal/legalbasis/the-constitutional-tribunal-act. 
the application of fundamental rights by Polish Constitutional Tribunal (PCT) with reference to the jurisprudence of the European Court of Human Rights (ECtHR, European Court) and Court of Justice of the European Union (CJ EU, EU Tribunal). The term 'reasoning' is, in the conceptions applied herein, used in the meaning of terms of argumentation, as concepts to be applied to similar relationships. The method of this research starts with a case study in combination with the comparative method.

In this context, not only reporting the reasoning but also statistical-quantitative and qualitative-analytical analyses may be helpful, in particular by determining the frequency with which the arguments are applied. Additionally, the role and perception of the decision-making bodies may be examined and the basic features of their constitutional reasoning and the style of their constitutional adjudication presented. This makes it possible to elaborate on domestic matters that may be of international interest from both the academic and professional points of view in greater detail.

The 30 most important Polish cases from the last 10 years that contain a substantive reference to CJ EU or European Court decisions were chosen for this study. ${ }^{15}$ All of them directly address fundamental issues of rights and the jurisprudence of ECTHR or CJ EU, which is the matter of detailed study and remarks above. From the latter perspective, as well as to ensure the relative consistency of the judgments under examination, jurisprudence has been selected that concerns criminal, civil, and medical cases. These branches of law-because of both the domestic and international character of standards and relevance to the concept of fundamental rights-seem the best platforms to present the coexistence of methods of argumentation presented by the national constitutional court and the international tribunals in question.

As a consequence, the 30 international decisions ( 27 given by ECtHR and 3 by CJ EU) considered are referred to by the Polish Constitutional Tribunal in its reasoning. In case of more than one such reference, a case (and decision) was chosen as relevant and presented. In other situations, the determining factor for the choice was the substantive influence in the opinion of the researcher.

Both Polish and international rulings will be presented in detail to show:

a) the methods of interpretation by the constitutional court;

b) the style of reasoning and decision-making characterizing the given constitutional court; and

c) the characteristics of the decision-making of the PCT in relationship with decisions of the ECtHR and CJ EU.

15 All the below mentioned judgments given by Polish Constitutional Tribunal with its reasoning are published in the database: http://otk.trybunal.gov.pl/orzeczenia/.

They (with justifications) are published in Polish with the pleadings filed by the parties to the proceedings.

Press release on some of the judgments of the PCT are published in these internet resources also in English. Some of these published translations regard the discussed cases and have been used in this paper below to report the late decisions. 
As far as the statistics and nature of the control are concerned, the discussed examples are mainly norm control cases and constitutional complaints. Sixteen of the examined constitutional court decisions were based on individual complaints concerning constitutional infringements (under Art. 79 of Constitution). Ten of the decisions were taken as the result of proceedings initiated by applications of entities generally legitimated for requesting a declaration of compliance with the Constitution (and indirectly-for interpreting the Polish Constitution of 1997), e.g. group of deputies. Finally, four of the presented cases were initiated by criminal and civil courts referring questions regarding the conformity of a normative act to the Constitution.

\subsection{Methods of interpretation, decision-making style, and issues of constitutional relevance in the selected judgments of the PCT}

\subsubsection{Substantive criminal law}

a. PCT judgment of 6 June 2011 and ECTHR case Janowski v. Poland of 21 January 1999 (criminal liability for public insult of the President of the Republic of Poland)

The Constitutional Tribunal in its judgment of 6 June 2011 (Ref. No. P 12/09) ${ }^{16}$ examined whether the provision criminalizing the public insult of the President of the Republic of Poland was consistent with Art. 54(1) (freedom of expression) in conjunction with Art. 31(3) (the principle of proportionality) of the Constitution, as well as with Art. 10 of the Convention for the Protection of Human Rights and Fundamental Freedoms (European Convention).

The Tribunal used the following methods of interpretation: contextual interpretation and analogy (argumentum a simile) referring to similar regulations. It was combined with a historical interpretation based on the relevant previous decisions of the Constitutional Court (as 'precedents'), and one based on scholarly works. The Tribunal noted that a sense of dignity and authority are among the prerequisites for the effective performance of the constitutional duties assigned to the Head of State. The President in office does not act in his own name, but in the name of the State, as the 'Head' thereof; he embodies the majesty of the Republic of Poland, and for that reason he is entitled to respect. ${ }^{17}$ What is more, the Tribunal ruled that this infringement of the freedom of expression is proportional and justified. First, the court has a wide range of non-custodial penalties for this crime. Second, freedom of expression is still guaranteed regardless of the examined provision. The right to criticize the President is preserved, and limited only in view of the specified form

16 See: https://trybunal.gov.pl/postepowanie-i-orzeczenia/wyroki/art/4766-odpowiedzialnosc-karnaza-publiczne-zniewazenie-prezydenta-rzeczypospolitej-polskiej.

17 See more: https://trybunal.gov.pl/en/news/press-releases/after-the-hearing/art/5682odpowiedzialnosc-karna-za-publiczne-zniewazenie-prezydenta-rzeczypospolitej-polskiej. 
(in particular when the form is offensive or humiliating). The limitation is therefore form-based, not content-based. ${ }^{18}$

The Tribunal used the Court's standard stated in the judgment of the European Court of Human Rights of 21 January 1999, Janowski v. Poland (application no. 25716/94) ${ }^{19}$ It was pointed out that the limits of freedom of expression should be formed strictly and enacted only when they are necessary, sufficient, and proportional. ${ }^{20}$ The Court assessed that this freedom is subject to exceptions, which must, however, be construed strictly, and the need for any restrictions must be established convincingly. The Contracting States have a certain margin of appreciation in assessing whether 'a pressing social need' exists, but it goes hand in hand with a European supervision, embracing both the legislation and the decisions applying it, even those given by an independent court. The Court is therefore empowered to give the final ruling on whether a 'restriction' is reconcilable with freedom of expression as protected by Art. $10 .{ }^{21}$

In the argumentation of PCT in favor of the constitutionality and conventionality of the regulation, the Tribunal directly applied the standards of freedom of expression formed by the European Court of Human Rights in the ruling on the abovementioned case. The Tribunal noted that according to the case-line of the Court, freedom of expression remains one of the foundations of a democratic society and deserves protection even if the content of the expression shocks or insults.

b. PCT judgment of 1 December 2016 and ECtHR case Zolotukhin v. Russia of 10 February 2009 (classifying the same act both as offense and as misdemeanor)

The provision controlled by the judgment of the Polish Constitutional Tribunal of 1 December 2016 (Ref. No. K 45/1422) governs the concurrence of provisions of the statutes: the Penal Code and the Code of Misdemeanors, i.e. a situation where a criminal act committed by a particular person meets the characteristics of both an offense and a misdemeanor. The Tribunal checked whether such regulation may stand in contradiction with the ne bis in idem principle, which prohibits conducting a trial and administering a penalty for the same act with regard to the same person twice, e.g. criminalizing a cause of disorder in a public place by shouting (a misdemeanor) and, at the same time, inciting others to commit a crime (an offense). ${ }^{23}$

18 See e.g. Górski, Klonowski, 2018, pp. 24-28.

$19 \mathrm{http}$ //hudoc.echr.coe.int/app/conversion/pdf/?library=ECHR\&id=001-45946\&filename $=001$ -45946.pdf.

20 The ruling in case Janowski v. Poland referred to a situation in which the applicant was convicted for insulting the civil servants during and in connection with carrying out his official duties (calling them 'oafs' and 'dummies'). According to the applicant, this decision infringed his right to express the opinion.

21 See para. 30 .

22 See: https://trybunal.gov.pl/postepowanie-i-orzeczenia/wyroki/art/9491-stosowanie-wobec-tej-samejosoby-za-ten-sam-czyn-odpowiedzialnosci-za-przestepstwo-i-za-wykrocze.

23 See: https://bit.ly/3kq50OS. 
The Tribunal stated that the provisions are consistent with the Polish Constitution as well as with Art. 4(1) of Protocol No. 7 to the Convention for the Protection of Human Rights and Fundamental Freedoms. According to the Tribunal applicant and the participants in the proceedings in the present case, sufficient attention was not paid to the rules of vertical systemic interpretation, which require that legal provisions should be interpreted in conformity with the norms of legal acts that are higher up in the hierarchy. ${ }^{24}$

The Tribunal in the procedure of judging used also the jurisprudence of the European Court of Human Rights, according to which in certain situations, reconviction or repetition of criminal proceedings for a certain criminal act does not lead to an infringement of the principle of ne bis in idem, expressed in Art. 4(1) of Protocol No. 7 to the Convention. In particular, the Tribunal focused on the judgment of 10 February 2009, Zolotukhin v. Russia (application no. 14939/03) ) $^{25}$ and the standard expressed in this case. The theses (paras. 82 and 84) of the last-mentioned Court judgment were used in the interpretation of the Polish Tribunal.

These parts of reasoning explain two dilemmas: when one may name the prosecution or trial 'second' in reference to the same offense; and what are the factors that the interpreter should take into account considering the res iudicata concerning the offense. The Court claimed that 'Art. 4 of Protocol No. 7 must be understood as prohibiting the prosecution or trial of a second "offense" in so far as it arises from identical facts or facts that are substantially the same'. ${ }^{26}$ The Tribunal used-following the Court-the method of interpretation based on the analysis of the general principle ne bis in idem. Second, the arguments were based on scholarly works. The main part of argumentation was based on the abovementioned interpretation of the European Convention.

c. PCT judgment of 12 February 2015 and ECtHR case Skatka v. Poland of 27 October 2003 (criminal liability for non-public insult of a civil servant)

The judgment of the Polish Constitutional Tribunal of 12 February 2015 (Ref. No. SK $70 / 13^{27}$ ) dealt with the problem of the infringement of an individual's freedom of expression in case of a non-public insult of the civil servant that causes criminal liability. This case-quite similar to the one referring to the constitutionality of the criminal liability for insult of the President of Republic of Poland-is important because the Constitutional Tribunal summed up its previous case law as regards the admissibility and rules of limiting the freedom of expression. It was pointed out that 'despite the exceptionally strong position of the freedom of speech in the constitutional axiology, the said freedom is not absolute in character and may be

24 Ibidem.

25 See: https://bit.ly/3ztjxNY.

26 Therefore, the interpreter should 'focus on those facts that constitute a set of concrete factual circumstances involving the same defendant and inextricably linked together in time and space, the existence of which must be demonstrated in order to secure a conviction or institute criminal proceedings'.

27 See: https://bit.ly/39m4JGk. 
subject to restrictions. When assessing the constitutionality of a regulation imposing a restriction on a constitutional right or freedom, it should be considered whether it meets formal criteria, i.e. whether it fulfils a premise that a restriction may only be introduced by statute; in the case of a reply in the affirmative to that basic question the so-called test of proportionality should be applied [including effectiveness, necessity, and proportionality in the strict sense]'. ${ }^{28}$

The main part of the interpretation referred to the significance of freedom of expression. The Tribunal used the interpretation of the Constitution on the basis of the case law of the Constitutional Court by referring to relevant previous decisions of the Constitutional Court. The Tribunal made use of the conventional standard pertaining to the protection of the freedom of expression, indicating the long list of case laws made by the European Court of Human Rights. One of the main aspects on which the Tribunal relied was expressed in the judgment of the European Court of Human Rights of 27 October 2003, Skałka v. Poland (application no. 43425/98). ${ }^{29}$

The following important part of the reasoning of Skałka v. Poland case-referring to the liability for insults about judges formulated in a letter-was a direct explanation of the borders of freedom of expression: 'The courts, as with all other public institutions, are not immune from criticism and scrutiny. Persons detained enjoy in this area the same rights as all other members of society. A clear distinction must, however, be made between criticism and insult. If the sole intent of any form of expression is to insult a court, or members of that court, an appropriate punishment would not, in principle, constitute a violation of Art. $10 \S 2$ of the Convention'. ${ }^{30}$

The insults about the judges of the Penitentiary Division of the Katowice Regional Court were formulated in a letter to the President thereof, and the European Court deemed that due to their appearance in an internal exchange of letters of which no one in the public was apprised, the administered penalty was disproportionately severe. ${ }^{31}$ At the same time-as the Polish Tribunal also observed-'the interference in question has to be "proportionate to the legitimate aims pursued" and the reasons adduced by the national authorities to justify it "relevant and sufficient". ${ }^{32}$

d. PCT judgment of 25 February 2014 and ECtHR case Handyside v. The United Kingdom of 7 December 1976 (criminal liability for 'incitement to hatred' and 'any other totalitarian system')

The Polish Constitutional Tribunal via the judgment of 25 February 2014 (Ref. No. SK 65/12) $)^{33}$ stated that Art. 256 of the Criminal Code-criminalizing 'the in-

28 See: Human rights and fundamental freedoms: the relationship of international, supranational and national catalogues in the 21st century. Questionnaire for the XVIIITH Congress of the Conference of European Constitutional Courts.

29 See: https://bit.ly/39iEfFK.

30 para. 34.

31 Ibid.

32 para. 35.

33 See: https://bit.ly/2XyUtsh. 
citement to hatred' as well as 'praising the Nazi, communist, or any other totalitarian system'-does not violate the Constitution. The constitutional problem was the use of vague expressions ('incitement to hatred' and 'any other totalitarian system') that could lead to breach of the nullum crimen sine lege principle.

The Constitutional Tribunal stated that Art. 256 of the Criminal Code does limit freedom of expression. However, this limitation fulfills the Constitutional criteria of proportionality, meaning that it is necessary in a democratic state in order to protect national safety and security as well as public order and citizens' rights. As the Tribunal pointed out, 'this limitation fulfills the legal requirements and is necessary in a democratic state. It has a strong justification on the basis of the Polish Constitution: It is grounded in the rule of the inherent and inalienable dignity of the human being (Art. 30 of the Constitution) and in the prohibition of political parties and any other organizations referring in their programs to totalitarian methods and practices of Nazism, fascism, and communism, but also those whose programs or activity allow racial and national hatred (Art. 13 of the Constitution).'. ${ }^{34}$

The Tribunal widely applied the interpretation of the Constitution on the basis of the case law of the Constitutional Court referring to the guarantees of personal liberty. What is more, the argumentation included the normative meaning of the general principle of nullum crimen sine lege. Additionally, the Tribunal-when weighing the values in the 'proportionality test'-used the notion of freedom of speech explained by the European Court of Human Rights in the ruling of the European Court of Human Rights of 7 December 1976, Handyside v. The United Kingdom (application no. $5493 / 72){ }^{35}$

The Court in this judgment defined the standard that should be observed to keep the regulation compliant with Art. 10 of the Convention. The 'restrictions' and 'penalties' limiting the freedom of speech must be: 'prescribed by law' and 'necessary in a democratic state'. Art. 10 para. 2 (Art. 10-2) leaves to the Contracting States a margin of appreciation. Nevertheless, it does not mean an unlimited power of appreciation. As the Tribunal found in this case, the protected freedom of speech is 'applicable not only to "information" or "ideas" that are favorably received or regarded as inoffensive or as a matter of indifference, but also to those that offend, shock, or disturb the State or any sector of the population. Such are the demands of that pluralism, tolerance, and broadmindedness without which there is no "democratic society". This means, among other things, that every "formality", "condition", "restriction", or "penalty" imposed in this sphere must be proportionate to the legitimate aim pursued'. ${ }^{36}$ 


\subsubsection{Procedural criminal law}

a. PCT judgment of 20 November 2012 and ECtHR case Kulikowski v. Poland of 19 May 2009 (extending of the pre-trial detention)

In the judgment of 20 November 2012 (Ref. No. SK 3/12), ${ }^{37}$ the Polish Constitutional Tribunal found the provision of Art. 263(7) of the Code of Penal Procedure to be unconstitutional because it did not unequivocally specify the provisions for extending pre-trial detention following the issue of the first sentence by a court of first instance in the relevant case. ${ }^{38}$ The constitutional control was based on Art. 41 para. 1 of the Constitution ('Personal inviolability and security shall be ensured to everyone'.. $)^{39}$

The Tribunal in this case had to specify the constitutional standard for extending the pre-trial detention. One of the main aspects of the judgment was the reference to the assessment of the application of pre-trial detention in Poland in the jurisprudence of the European Court of Human Rights. The Tribunal expressis verbis noted that is not bound by the judgments of the European Court. However, the Tribunal has to take into account, as part of its constitutional review, the norms and standards formulated by the Court in order to eliminate any possible collisions between them. The standards contained in the Convention and the jurisprudence of the Court may therefore be referred to as an element of argumentation and thus serve to maintain the relative uniformity of decisions of legal protection authorities adjudicating on the basis of the provisions of domestic and international law. ${ }^{40}$

In this context, the Tribunal pointed out the circumstances indicated in the jurisprudence of the Court as the reasons for Poland's violation of Art. 5 sec. 3 of the European Convention. In particular, the Tribunal referred to the judgment of the European Court of Human Rights of 19 May 2009, Kulikowski v. Poland (application no. $18353 / 03){ }^{41}$

The relevant aspect of this case was that used by the Polish Tribunal in the case commented above. The European Court noted that 'the reasonable suspicion against the applicant of having committed a serious offense could initially warrant his detention. Also, the need to secure the proper conduct of the proceedings, in particular the process of obtaining evidence from witnesses, constituted valid grounds for the applicant's initial detention. (...) [Nevertheless], with the passage of time,

37 See: https://bit.ly/2VVml8V.

38 See e.g. Wiśniewski, 2020, p. 176.

39 Any deprivation or limitation of liberty may be imposed only in accordance with principles and under procedures specified by statute in connection with the proportionality principle (Art. 31 para. 3 of the Constitution), as well as on the Art. 40 ('Personal inviolability and security shall be ensured to everyone. Any deprivation or limitation of liberty may be imposed only in accordance with principles and under procedures specified by statute') connected with Art. 41 para. 4 ('Anyone deprived of liberty shall be treated in a humane manner').

40 Para. 3.2 of the judgment.

41 See: https://bit.ly/3nLMa73. 
those grounds became less and less relevant. The Court must then establish whether the other grounds adduced by the courts-namely, the severity of the anticipated sentence-were "relevant" and "sufficient". ${ }^{42}$ The main conclusion of the Court in this aspect was that the gravity of the charges cannot by itself justify long periods of detention pending trial.

b. PCT judgment of 11 October 2016 and ECtHR case van der Valen v. Netherlands of 7 December 2006 (terms of taking samples of biological material from an accused person)

The Polish Constitutional Tribunal by the judgment of 11 October 2016 (Ref. No. SK $28 / 15)^{43}$ held that the necessity of taking a cheek swab occurs when such evidence is a prerequisite for determining or identifying a perpetrator and for holding him/her criminally liable or for protecting an innocent person from being wrongly held criminally liable. ${ }^{44}$ Hence, the controlled provision was found consistent with the right to privacy and the right to personal inviolability. The Tribunal stated that not only personal inviolability but also the right to privacy and informational selfdetermination do not have an absolute character and may be subject to restrictions in compliance with the rules of proportionality. In its judgment the Tribunal found that the regulation is not only useful, but also necessary and balanced. ${ }^{45}$

There were various methods of interpretation applied in the reasoning: from one based on precedents of the Polish Tribunal, to scholarly works from Poland, to the standard of personal rights in European states. The Tribunal used some case law of the European Court in this judgment, referring to many aspects, especially the right to avoid self-incrimination and the right to privacy in connection with gathering the DNA data.

It is worth emphasizing the explicit reference to the judgment of 7 December 2006, van der Valen v. Netherlands (application no. 29514/05). ${ }^{46}$ The Court answered the question about the proportionality of the gains and loses concerning taking a cheek swab in the criminal procedure. The Tribunal-after the European Court's indicated ruling - noted that the intervention breaches personal inviolability minimally and does not entail suffering. What is more, the Tribunal followed the Court in stating that the procedure may be beneficial for the examined individualprotecting an innocent person from being wrongly held criminally liable.

The background of the case van der Valen v. Netherlands was similar to the Polish one. The applicant was convicted for certain crimes, and the public prosecutor ordered that cellular material be taken from him in order for his DNA profile to be determined. In reference to the severity of the measure imposed, the Court found

42 Paras. 45-47.

43 See: https://bit.ly/3hL5v4b.

44 See: https://bit.ly/39ACF21.

45 About the issue of using DNA data in the constitutional perspective see: Wójcikiewicz, Kwiatkowska-Wójcikiewicz, 2017, pp. 207-222.

46 See: https://bit.ly/391212B. 
that the severity of the measure was not decisive. What is more, the Court accepted with no doubts that the compilation and retention of a DNA profile served the legitimate aims of the prevention of crime and the protection of the rights and freedoms of others.

The importance of this case for the interpretation of Polish constitutional template is expressed in the following notes of the Court: 'it is to be noted that while the interference at issue was relatively slight, the applicant may also reap a certain benefit from the inclusion of his DNA profile in the national database in that he may thereby be rapidly eliminated from the list of persons suspected of crimes in the investigation of which material containing DNA has been found'.

c. PCT judgment of 25 November 2014 and ECtHR case Brennan v. United Kingdom of 16 October 2001 (lack of the possibility of telephone communication between a person detained and counsel for the defense)

In the judgment of 25 November 2014 (Ref. No. K 54/13), ${ }^{47}$ the Polish Constitutional Tribunal held that an absolute prohibition against the use of a telephone by a person detained pending trial for the purpose of communicating with his/her counsel for the defense is inconsistent with Art. 42 para. 2 of the Constitution ${ }^{48}$ in connection with the principle of proportionality. ${ }^{49}$

The Tribunal deemed that the complete exclusion of telephone communication between a person detained pending trial and his/her counsel for the defense restricted the right to defense and was not necessary, but might be justified by concern that the accused would urge that false testimony be given or would, in another unlawful way, obstruct criminal proceedings. ${ }^{50}$

The basic method of interpretation was interpretation on the basis of the case law (precedents) of the constitutional tribunal. What is more, numerous scholarly works of Polish doctrine were used in the arguments. The Tribunal discussed also the standard of guarantees in other European countries (comparative law arguments).

The Tribunal recalled the argumentation expressed in many rulings of European Court of Human Rights-underlining the case law on the right to defense and the right to private life. The Tribunal recalled in particular the judgment of the Court of 16 October 2001, Brennan v. United Kingdom (application no. 39846/98) ${ }^{51}$ and emphasized that enabling the accused to communicate freely with his or her lawyer is a

47 See: https://bit.ly/2XFiZb3.

48 'Anyone against whom criminal proceedings have been brought shall have the right to defense at all stages of such proceedings. He may, in particular, choose counsel or avail himself-in accordance with principles specified by statute-of counsel appointed by the court'.

49 About the constitutional and conventional standard of defense rights see more e.g. Steinborn, 2019, pp. 38-46.

50 What is more, in its opinion, the complete deprivation of that form of contact in the case of a person detained pending trial undermines adherence to the principle of equality of arms in criminal proceedings.

51 See: https://bit.ly/3AuqY91. 
condition for the effective exercise of the right to defense. Although this guarantee is not absolute, its limitations are considered admissible only if it is sufficiently justified and if it does not invalidate the right to a fair hearing.

The Court in the case of Brennan v. United Kingdom-in terms of the deferral of access to the applicant's solicitor-noted that the measures taken by the police concerning the applicant's access to his solicitor should be compatible with the rights of the defense. The Court recalled also its case law, according to which 'Art. 6 will normally require that the accused be allowed to benefit from the assistance of a lawyer already at the initial stages of police interrogation; this right, which is not explicitly set out in the Convention, may be subject to restriction for good cause. The question in each case is whether the restriction, in the light of the entirety of the proceedings, has deprived the accused of a fair hearing, ${ }^{52}$

d. PCT judgment of 11 December 2012 and ECtHR case Rybacki v. Poland of 13 January 2009 (right to defense in the criminal proceedings)

In its judgment of 11 December 2012 (Ref. No. K 37/11), ${ }^{53}$ the Polish Constitutional Tribunal held that the provision in the Criminal Proceedings Code referring to the right of the detained person to contact with an advocate to an extent that does not indicate a premise that entitles the detainee to be present at the interview with an advocate, is inconsistent with Art. $42 \mathrm{sec} .2$ ('Anyone against whom criminal proceedings have been brought shall have the right to defense at all stages of such proceedings. He may, in particular, choose counsel or avail himself-in accordance with principles specified by statute-of counsel appointed by the court') in connection with Art. $31 \mathrm{sec} .3$ of the Constitution of the Republic of Poland (the principle of proportionality. ${ }^{54}$

In the judgment of the European Court of Human Rights of 13 January 2009, Rybacki v. Poland (application no. 52479/99), ${ }^{55}$ the applicant complained inter alia that for the over five months of his detention he could not communicate with his lawyer out of earshot of the prosecutor or a person appointed by him. ${ }^{56}$ The Court noted that 'although not absolute, the right of everyone charged with a criminal offense to be effectively defended by a lawyer, assigned officially if need be, is one of the fundamental features of fair trial'. Hence, the right of the defendant to

52 See also judgment of 8.2.1996, John Murray v. the United Kingdom, paras. 54-55, 63; https://bit. ly/3tWQ8Le.

53 See: https://bit.ly/2XGwSFY.

54 About the access to the defense see more e.g. Sakowicz, 2019, pp. 47-54. In particular the comment: 'The European Court of Human Rights held that access to a defense lawyer should be the rule if the suspect's confession is to be used as evidence in the case. The above assumption was extended to apply also to vulnerable suspects. While analyzing ECtHR case law and provisions of the Polish Code of Criminal Procedure, an attempt is made to deduce a prohibition of using the suspect's statements as evidence if the suspect appears without a defense lawyer or when the defense lawyer is absent'. Ibid., p. 54.

55 See: https://bit.ly/3nJXoca.

56 Para. 50. 
communicate with his advocate out of hearing of a third person-although perhaps subject to certain restrictions-is part of the basic requirements of a fair trial in a democratic society. The State should prove that there were sufficient grounds for the imposition of the measures complained of. ${ }^{57}$

In the discussed judgment of the PCT, the importance of the right to defense (at the beginning of the criminal trial) was underlined as demanding the use of the standard expressed by the European Court. According to the national tribunal, the Court explicitly assumes that one of the basic elements of the right to defense is the possibility of contact with a lawyer beyond the hearing of a third partye.g. from the perspective of reasoning in the case Rybacki v. Poland. The Tribunal held-using inter alia the reasoning of the mentioned ruling, that the right to unhampered legal advice by a detainee at the initial stage of the criminal proceedings is crucial to ensuring an effective opportunity to defend himself at a later stage of the proceedings.

e. PCT judgment of 10 December 2012 and ECtHR case Silver and Others v. The United Kingdom of 25 March 1983 (terms of communication between a person detained and counsel for the defense)

The Constitutional Tribunal by the judgment of 10 December 2012 (Ref. No. K 25/11) adjudicated that Art. 73(3) of the Act of 6.6.1997, the Polish Code of Criminal Procedure, due to the fact that it indicated no premises whose occurrence would authorize a prosecutor to permit the monitoring of correspondence carried out between a suspect and his/her counsel for the defense, was inconsistent with Art. 42(2) in conjunction with Art. 31(3) of the Constitution. ${ }^{58}$

As may be noted, the relevant constitutional provisions in the case are the same as in the judgment commented upon above. The main problem with the controlled regulation of the criminal procedure was that it did not indicate the premises whose occurrence would authorize a prosecutor to permit the monitoring of correspondence carried out between a suspect and his/her counsel for the defense.

The Tribunal used arguments based on scholarly works-Polish monographs and articles. Furthermore, there were many aspects (e.g. the right to defense) where the Tribunal referred to the Polish constitutional precedents. The Tribunalusing the conventional standard derived from the jurisprudence of the European Court-found that correspondence between a detained person and his advocate should be particularly privileged due to the guarantee resulting from the right to obtain professional legal advice. The test of proportionality (statutory limitation, arbitrariness) of the regulation was not fulfilled according to the judgment of the European Court of Human Rights of 25 March 1983, Silver and Others v. The

57 Paras. 56 and 59.

58 See: https://bit.ly/3kodhms. 
United Kingdom (application no. 5947/72; 6205/73; 7052/75; 7061/75; 7107/75; 7113/75; 7136/75). ${ }^{59}$

The Court stated that, irrespective of the nature of correspondence, it should not be opened, except where there is a reasonable suspicion that the correspondence is being used for illegal purposes. As the judgment stated, 'the Court does not interpret the expression "in accordance with the law" as meaning that the safeguards must be enshrined in the very text that authorizes the imposition of restrictions. In fact, the question of safeguards against abuse is closely linked with the question of effective remedies'. Further, the phrase 'necessary in a democratic society' should be treated as: 1 . not synonymous with 'indispensable'; neither does it have the flexibility of such expressions as 'admissible', 'ordinary', 'useful', 'reasonable', or 'desirable'; 2. leaves a certain but not unlimited margin of appreciation in the matter of the imposition of restrictions; 3. the interference must, inter alia, correspond to a 'pressing social need' and be 'proportionate to the legitimate aim pursued'; and 4. exceptions to a right guaranteed are to be narrowly interpreted. ${ }^{60}$

f. PCT judgment of 21 January 2014 and ECtHR case W.S. v. Poland of 19 June 2007 (terms of appointing a guardian for a minor who is the aggrieved party in criminal proceedings)

The next discussed judgment of the Polish Constitutional Tribunal of 21 January 2014 (Ref. No. SK 5/12) ${ }^{61}$ stated that the risk of a conflict between the interest of a parent who wished to represent the child in proceedings pending against the other parent and the interests of the child would be minimalized only by introducing into criminal proceedings a guardian, as an unbiased representative of a minor. . Such a solution also guaranteed that decisions made to exercise the rights of the minor as the aggrieved party would be as unbiased as possible. In addition, the Tribunal mentioned risks posed by the necessity to evaluate-at the onset of preliminary proceedings - whether a given parent could represent the minor in a proper way. ${ }^{62}$

The right to a child's hearing must not lead to this very value being completely ignored. In weighing these values, the Tribunal pointed to the judgment of the European Court of Human Rights of 19 June 2007, W.S. v. Poland (application no. $21508 / 02){ }^{63}$ In conclusion, it noted that from the point of view of international standards of human rights protection, the problem of the Polish criminal procedure turned out to be the defect in the defendant's right to defense, and not the regulation on hearings involving a child.

In the opinion of the Tribunal's ruling commented above, the crux of the case W.S. v. Poland concerned the accused's right to a fair trial in relation to his or her

59 See: https://bit.ly/2Xu86s7.

60 See para. 97.

61 See: https://bit.ly/2Z8bXvH.

62 See: https://bit.ly/2XzB8ao.

63 See: https://bit.ly/3ApVDEB. 
right to defense in criminal proceedings. The Court found that 'in criminal proceedings concerning sexual abuse certain measures may be taken for the purpose of protecting the victim, provided that such measures can be reconciled with an adequate and effective exercise of the rights of the defense. ${ }^{64}$ The main argument justifying the position of the European Court was the statement that the Polish court based the sentence of the father, accused of molesting his child, solely on the opinion of an expert psychologist interpreting the child's testimony.

The method used widely in this judgment was one referring to the arguments from scholarly works formulated following Polish doctrine. What was important in this ruling, in the view of the European Convention's standard, was the significance of the right of the accused to defend himself, even if the accused was one of the child's parents and the offense consisted in acting against the child.

\subsubsection{Private law: Protection of property and personal data}

a. PCT judgment of 23 October 2012 and ECtHR case Broniowski v. Poland of 22 June 2004 (compensation for immovable properties left outside the present borders of Poland after World War II)

In its ruling of 23 October 2012 (Ref. No. SK 11/12), ${ }^{65}$ the Tribunal evaluated the terms of applying for compensation for immovable properties left outside the present borders of Poland after World War II. It was judged that the requirement that the right to compensation be granted on condition that the former owners of immovable properties located in the pre-WW-II eastern territories of the Second Republic of Poland resided in those territories on 1 September 1939 was inconsistent with the Constitution. The Tribunal adjudicated that Art. 2(1) of the Act of 8.6.2005 on exercising the right to compensation arising from leaving immovable properties outside the present borders of the Republic of Poland, insofar as it provided for the right to compensation to be granted on condition that the former owners of immovable properties resided in the pre-war eastern territories of the Second Republic of Poland on 1 September 1939, was inconsistent with Art. 64(2) in conjunction with Art. 31(3) of the Constitution. ${ }^{66}$ The Court explained that the right to compensation for immovable properties located in the pre-WW II eastern territories of the Second Republic of Poland is a compensatory property right that falls within the scope of public law and is subject to protection on the basis of Art. 64 of the Constitution. The challenged requirement that the former owners of immovable properties located in these eastern territories of the Second Republic of Poland resided in those territories on 1

64 Para. 57.

65 See: https://bit.ly/39m0OcG.

66 The above provision ceased to have effect after the lapse of 18 months from the date of the publication of the judgment in the Journal of Laws. As to the remainder, the Tribunal discontinued the proceedings. The decision to defer the effects of the judgment was justified both by its potential financial consequences for the situation of the Restitution Fund as well as by the considerable degree of complexity of the matters under analysis. 
September 1939 constitutes a restriction of that right that is subject to examination in the light of the principle of proportionality (Art. 31(3) of the Constitution). ${ }^{67}$

The Constitutional Tribunal emphasized that the legislator enjoyed considerable freedom as regards determining the terms of granting compensation and the forms thereof with regard to immovable properties located in the pre-war eastern territories of the Second Republic of Poland. However, this did not imply an automatic approval of every kind of criterion for access to such benefits that made it possible to adjust the said compensation to the capacity of the state budget. Indeed, even the smallest amounts of funds might, and should, be allocated on the basis of provisions that met constitutional standards.

In its justification, the tribunal referred expressly to the jurisprudence of European Court of Human Rights, in particular to the ruling of 22 June 2004, Broniowski v. Poland (application no. 31443/96 ${ }^{68}$ ). The Court (Grand Chamber) held that there had been a violation of Art. 1 of Protocol No. 1 of Convention. It found that that violation had originated in a systemic problem connected with the malfunctioning of domestic legislation and practice caused by the failure to set up an effective mechanism to implement the 'right to credit' of Bug River claimants, ${ }^{69}$ with the consequence that not only the applicant in this particular case but also a whole class of individuals had been or were still denied the peaceful enjoyment of their possessions. ${ }^{70}$ In connection with this, the Court directed that the respondent State should, through appropriate legal measures and administrative practices, secure the implementation of the property right in question in respect of the remaining Bug River claimants or provide them with equivalent redress in lieu, in accordance with the principles of protection of property rights under Art. 1 of Protocol No. $1 .^{71}$

The Polish Constitutional Court did strengthen its argumentation by reference to European Court stating that, in respect of the award to the applicant for any pecuniary or non-pecuniary damage resulting from the violation found in the present case, the Court held that the question of the application of Art. 41 of the Convention was not ready for decision and reserved that question as a whole, inviting the Government

67 In the opinion of the Tribunal, the requirement is excessively restrictive. The persons who left the pre-war eastern territories of the Second Republic of Poland due to the outbreak of the war in 1939, could not have predicted rationally that possible compensation for the lost immovable properties would be conditioned by residing in the former territories of the Polish State during a special and very brief period in the distant past (only one day-1 September 1939). Indeed, during the years of the Second Republic of Poland (the period between the wars), the scope of the protection of ownership as regards immovable properties was in no way conditioned by the place of residence, and the provisions that were binding at that time permitted having a few places of residence. Additionally, when enacting the challenged regulation, no analysis was carried out with regard to alternative solutions, followed by the choice of the one that was the most fair and that implemented the aim of the Act to the largest extent, and that introduced only necessary restrictions and differentiation.

68 See: https://bit.ly/39i7CYS.

69 Point 3 of the judgment.

70 Para. 189.

71 Point 4 of the judgment. 
and the applicant to submit, within six months from the date of notification of the principal judgment, their written observations on the matter and to notify the Court of any agreement they might reach. ${ }^{72}$

In greater detail, with respect to Art. 41, the Court considered that that issue should be resolved, not only with regard to any agreement that might be reached between the parties but also in the light of such individual or general measures as might be taken by the respondent Government in execution of the principal judgment. Pending the implementation of the relevant general measures, the Court adjourned its consideration of applications deriving from the same general cause. ${ }^{73}$ This argumentation was also directly applied by Constitutional Tribunal.

b. PCT judgment of 7 March 2018 and ECtHR case Beyeler v. Italy of 5 January 2000 (limitation to ownership caused by environmental protection)

In the judgment of 7 March 2018 (Ref. No. K 2/17), ${ }^{74}$ the Constitutional Tribunal judged the case of limitation to proprietary rights sensu largo. The Tribunal adjudicated that Art. 129 (4) of the Act of 27.4.2001 on Environmental Protection was inconsistent with Art. 64(1) in conjunction with Art. 31(3) of the Constitution. During these proceedings, the arguments covering the interpretation of Art. 1 of Protocol No. 1 to the Convention for the Protection of Human Rights and Fundamental Freedoms were presented and de facto granted by the tribunal. They included the principle of 'fair balance' presented in the jurisprudence of the European Court.

The Court in its judgment of 5 January 2000, Beyeler v. Italy (application no. $33202 / 96^{75}$ ) stated that, in order to be compatible with the general rule, an interference with the right to the peaceful enjoyment of 'possessions', apart from being prescribed by law and in the public interest, must strike a 'fair balance' between the demands of the general interest of the community and the requirements of the protection of the individual's fundamental rights. ${ }^{76}$

Polish Constitutional Court de facto used-as the argument in its reasoningthe observation that in the jurisprudence of ECtHR it has been pointed out that this rule does not prohibit even significant restrictions on the property rights, so long as they are accompanied by legal instruments that maintain a proper balance between public and private interests. Important factors creating this appropriate balance are: awareness of the introduced restrictions and the ability to predict their future effects, the size of the restrictions, the possibility of questioning the validity of the restrictions introduced, and the mechanism of compensation claims. On the 
other hand, the difficult, and in many cases even inaccessible, possibility of taking advantage of the provisions provided for in Art. 129 (1-3) of the Act was claimed not to strike a fair balance between public and private interests. Detailed practical examples of national solutions that were given in this European Court jurisprudence and that may update the negative assessment from the perspective of Art. 1 were also applied in the process of creating the national control standard.

\section{c. PCT judgment of 24 April 2018 and ECtHR case Michat Korgul v. Poland of 21} March 2017 (exercise of ownership by convicted persons)

In the judgment of 24 April 2018 (Ref. No. SK 27/16), ${ }^{77}$ the Constitutional Tribunal judged (with regard to a constitutional complaint) the exercise of the right of ownership by convicted persons serving prison sentences. The Tribunal adjudicated that Art. 126(10) of the Act of 6.6.1997-the Executive Penal Code-insofar as it does not allow a convicted person to use personal funds referred to in Art. 126(1) of the said Act to pay for a fine if the fine was not substituted with a prison sentence or with detention, is consistent with Art. 64(1) in conjunction with Art. 64(3) of the Constitution of the Republic of Poland.

The allegations raised in the constitutional complaint did not concern the entire category of so-called 'frozen funds' provided for in Art. 126 of the Executive Penal Code, but a certain element thereof. ${ }^{78}$ Before the Tribunal assessed the validity of the allegation, it analyzed provisions on the keeping and disposal of funds belonging to a convicted person, as well as provisions regulating the replacement of a fine with a substitute penalty of confinement. First, the Tribunal held that money that is to be kept as 'frozen funds', due to the nature of that legal construct, does not in principle comprise all money belonging to a convicted person or all money obtained from the sources mentioned in Art. 126(2) of the Executive Penal Code-in every case, it is only a certain percentage of those funds. ${ }^{79}$ Second, the Tribunal considered the fact that the mechanism regulated in the provisions of the Executive Penal Code was constructed in such a way that even if a convicted person's only money is the money accumulated as 'frozen funds', this does not rule out the payment of a fine imposed on that person. Indeed, in the case where the said person has no money for the enforcement of the fine to be carried out, a competent court orders the administration of a substitute penalty of the deprivation of liberty, which the convicted person may

77 See: https://bit.ly/2VTjugI.

78 The complainant challenged the solution that Art. 126(10) of the Code did not allow a convicted person to use his/her accumulated 'frozen funds' to pay a fine that had not be substituted with a prison sentence or with detention. According to the complainant, that restriction was too far-reaching, as the indicated provision should permit the use of a convicted person's 'frozen funds' for the payment of his/her fine, regardless of the fact whether the fine had been replaced with a substitute penalty.

79 Every incoming amount of money (except for an amount deposited by a convicted person at the time of being admitted to prison) is subject to a one-off reduction by an amount not higher than $4 \%$ of average remuneration of workers. Thus, convicted persons may use the remaining funds to pay for their fines, or this could be done by convicts' close persons. 
object to by filing an application pursuant to Art. 126(10) of the Executive Penal Code. ${ }^{80}$

The Tribunal expressly accented-similarly to the reasoning presented by ECtHR-that the legislator had weighed the respective interests in the examined situation: First, the intention to provide convicted persons with basic financial means after their release from prison (by creating the legal construct of 'frozen funds', which serves rehabilitative goals and the protection of the public order); second, the avoidance of the further confinement of convicted persons, and hence the introduction of an exception that 'frozen funds' may be used for paying a fine if it substitutes for a prison sentence or detention (which constitutes a warranty measure with regard to convicted persons). Taking this into consideration, the Tribunal stated that the legislator had not exceeded the constitutional limits of admissible interference with the property rights of convicted persons, and that he had balanced the necessity to protect those rights with the need to protect public order and with the assumption that prolonging the confinement of convicts should be avoided.

In the mentioned judgment of 21 March 2017, Michał Korgul v. Poland (application no. $36140 / 11^{81}$ ) the applicant, a Polish national, was detained. The European Court of Human Rights stated that the state has the right to use such programs (systems) that it considers most appropriate for reintegrating prisoners into society after their release, including by securing a certain amount of money for them. ${ }^{82}$ In this case the European Court expressly declared that the state has the right to use programs (systems) that it deems most appropriate for the reintegration of prisoners into society after their release, including by securing a certain amount of money for them.

It should be added that the Polish Constitutional Tribunal also noted that the institution of 'frozen funds' can be treated as an element of the implementation of Principle 6 of Recommendation $\operatorname{Rec}(2006) 2$ of the Committee of Ministers to member states on the European Prison Rules ${ }^{83}$ regarding facilitating the reintegration of persons deprived of liberty into a free society. Although this recommendation is

80 The Tribunal noted that the legislator's assumption was that a convicted person should pay his/her fine from money that had not been included in 'frozen funds'. Such an assumption is linked with the legal construct of 'frozen funds' as a certain savings (accumulated money) plan which is to provide convicted persons with financial means to travel home after their release from prison and to support themselves. When creating the legal construct of 'frozen funds', the legislator also provided for an instrument on the basis of which-and in compliance with certain requirements-convicted persons may pay their fines with money accumulated as 'frozen funds', but only after the enforcement of the fine proves ineffective or if it follows from the circumstances of a case that the said enforcement would be futile.

81 See: https://bit.ly/3hP1j3L.

82 The case essentially concerned his complaint about the high-security measures to which he had been subjected in the context of criminal proceedings brought against him for armed robbery. He was classified as a dangerous detainee and placed under a high-security regime for two periods covering nearly two years. These security measures were applied and extended on the ground that he had been aggressive and threatening to prison guards.

83 See: https://bit.ly/3EBhWcU. 
not binding, the solutions contained therein are treated as determining the way of shaping penitentiary systems in the legal orders of individual member states of the Council of Europe.

d. PCT judgment of $30 \mathrm{Jul} 2014$ and CJ EU case Digital Rights Ireland Ltd v. Minister for Communications, Marine and Natural Resources, Ireland; Kärntner Landesregierung v. M. Seitlinger and others of 8 April 2014; C-293/12, C-594/12 (information on the individual gathered in operational activities)

The PCT judgment of 30 July 2014 (Ref. No. K 23/11) ${ }^{84}$ refers to technical (telecommunication) data retention and covert surveillance. PCT resolved the issue of granting access to telecommunications data retained by service providers and-what is important from the perspective of protection of personal data-retaining them. It was judged inter alia that some questioned provisions of acts on operational activities $^{85}$ were inconsistent with Arts. 42(2), 47, 49, 51(2), and 54(1) of the Constitution in conjunction with Art. 31(3) insofar as they did not provide for a guarantee that materials that contained information that was prohibited from being evidence should be subject to immediate, witnessed, and recorded destruction in a case where the court had not lifted professional confidentiality requirements. ${ }^{86}$

What is interesting is that the statute provisions under review were closely related to the scope of application of Directive 2006/24/EC ${ }^{87}$ (although they did not implement this EU law). The issue of compliance of the provisions on telecommunications data retention with fundamental rights was in fact common to the many Member States. Similar regulations were assessed also by national constitutional courts and the CJEU. The jurisprudence of the ECtHR was also important in determining the standard of protection of fundamental rights. First of all, it should be noticed the decision of PCT was influenced by reasoning presented by EC EU that considered Directive 2006/24/EC invalid. PCT answered the legal question of the impact of the annulment of the directive on constitutionality of national provisions and review in the pending case. When declaring the unconstitutionality of the

84 See: https://bit.ly/3lDoRcY.

85 I.e. Police, Border Guard, tax audit, Military Police, Internal Security Agency and Foreign Intelligence Agency, Military Counter-Intelligence Service and the Military Intelligence Service, and the Central Anti-Corruption Bureau.

86 The freedom of privacy in the digital age is constitutionally protected and implies that individuals are at liberty to act within the scope of that freedom as long as a relevant statute does not delineate its scope. The Tribunal explained that protection arising from theses articles comprises all ways of transferring information in every form of communication, regardless of means used (e.g. conversations in person and on the phone, written correspondence, fax, SMS and MMS messages, email, exchanging messages via portals). The said protection pertains not only to the content of a communication but also to the circumstances of the communication.

See the detailed description in English: https://bit.ly/3tUVqXg.

87 Directive 2006/24/EC of the European Parliament and of the Council of 15 March 2006 on the retention of data generated or processed in connection with the provision of publicly available electronic communications services or of public communications networks and amending Directive 2002/58/EC; OJ L 105, 13.4.2006, pp. 54-56. 
above-mentioned provisions on data retention, PCT referred also to the standard indicated in the CJEU judgment of 8 April 2014, Digital Rights Ireland Ltd v. Minister for Communications, Marine and Natural Resources, Ireland; Kärntner Landesregierung v. M. Seitlinger and others (C-293/12, C-594/12).$^{88}$ As a result, the standard of secret surveillance implemented by PCT is a kind of composition of requirements previously presented by CJ EU (and indirectly by the jurisprudence of ECtHR, taken into consideration by PTC and CJ EU) with additional domestic requirements. ${ }^{89}$ This comes as no surprise, given the similar wording of the constitutional provisions and Arts. 7-8 of the EU Charter of Fundamental Rights (protection of private life and protection of personal data).

\subsubsection{Private law: Civil liability and compensation}

a. PCT judgment of 23 Jun 2015 and CJ EU case ACI Adam BV and others against Stichting de Thuiskopie, Stichting Onderhandelingen Thuiskopie vergoeding of 10 April 2014 (culpable infringement of copyright)

The issues of liability for infringement of copyright and the amount of damages were the subject of two pending proceedings before the national court in recent years.

For the first time, in judgment of 23 June 2015 (Ref. SK 32/14) ${ }^{90}$ the Tribunal judged that Art. 79 (1.3.b in fine) of the Act of 4.2.1994 on copyright and related rights was partly inconsistent with Art. 64 (1-2) in connection with Art. 31 (3) and Art. 2 of the Constitution of the Republic of Poland. This concerned the extent to which the entitled, whose economic copyrights had been infringed, may request the person who infringed those rights to remedy the loss caused: on the basis of general principles, or -in the event of a culpable infringement—by payment of a sum of money corresponding to three times the amount of the appropriate fee that would have been due at the time it was sought if the rightholder had given permission for the work to be use. ${ }^{91}$

The abovementioned provision was based on a mechanism that 'distracted' the question of the infringer's liability from the damage caused by its actions and, moreover, made it possible to completely disregard the kind of 'unlawfulness' that

88 See: https://bit.ly/2Z3cgIb.

89 It is discussed in the legal literature that the issue at stake is common within the European case law and the PCT and the European courts create a standard for the protection of freedom of communication and privacy. See the detailed remarks: Podkowik, Zubik, 2021, pp. 155-173.

90 See: https://bit.ly/3ApsERi.

91 See more: Gęsicka, 2015, pp. 205-218. The author stresses that: 'it might be deduced that the Tribunal indirectly advocated an alternative damage claim that would refer to a single lump sum (royalty fee). Nevertheless, such an approach might turn out to become an obstacle for non-professional right holders, mostly the authors themselves, to be compensated for the entire damage. The judgment thus lacks consistency as well as proper justification and that is the reason for the Author's only partial approval of it' (pp. 217-218). 
had emerged in this case. ${ }^{92}$ In the opinion of the Tribunal, the legislator had disturbed the balance between the position of the copyright holder and the perpetrator of the damage.${ }^{93}$ Additionally, the Tribunal emphasized that a victim whose property rights have been violated may be granted various protective legal instruments. Nevertheless, he should not have at his disposal such instruments as would indicate that the legislator itself guarantees excessive interference with the property rights of the ex delicto liable. Since, as a rule, such a basic protective instrument is compensation determined within the limits of an adequate causal link, even the introduction of lump sum elements may not lead to a complete loss in legal provisions of the issue of proportion between the amount of damage suffered and that compensation.

As the justification of this ruling, the Polish Tribunal explicitly referred to the judgment of the Court of Justice of the European Union of 10 April 2014 (ACI Adam BV and others against Stichting de Thuiskopie, Stichting Onderhandelingen Thuiskopie vergoeding, C-435/12 ${ }^{94}$ ). The reasoning of this ruling expresses inter alia the statements that the EU law 'must safeguard a fair balance between the rights and interests of authors, who are the recipients of the fair compensation, on the one hand, and those of users of protected subject-matter, on the other' (53) and 'satisfying the condition of the fair balance to be found between, on the one hand, the rights and interests of the recipients of the fair compensation and, on the other, those of those users' (57). These statements were recalled by the Tribunal to strengthen the grounds of the judgment given.

\section{b. PCT judgment of 5 November 2019 and CJ EU case 'Oławska Telewizja Kablowa'} $w$ Oławie $v$ Stowarzyszenie Filmowców Polskich $w$ Warszawie of 25 January 2017 (compensation of infringement of copyright)

In the second case, the Tribunal in its judgment of 5 November 2019 (Ref. No. P 14/19) ${ }^{95}$ ruled that the remaining part of Art. 79 (1.3.b in initio) of the Act of 4.2.1994

92 The court to which the entitled person referred his claim, applying the challenged regulation, examined only the conditions for liability for damages in the challenged provision, but did not take into account any further circumstances that could affect the scope of the applicant's liability. In particular, the court did not take into account the detailed context underlying the infringement, related to the negotiation of the amount of the license fee in the situation of rather limited freedom of contract.

93 While the entitled person has strong institutionalized protection, enjoys a whole catalogue of claims triggered in connection with infringement of author's economic rights, as well as procedural facilities (information claims), the legislator additionally equipped him with an instrument of protection consisting in demanding a flat-rate compensation that does not require establishing the amount of damage, or even completely detached from it. On the other hand, the perpetrator of the tort, which is held liable separately from the known from Art. 361 of the Civil Code the principle of adequate causation, he does not have any effective instruments enabling him to defend himself and minimize the incurred damage to property. Not only is his responsibility not limited to the normal consequences of the action (...) from which the damage resulted', but may exceed them several (three) times.

94 See: https://bit.ly/39mX2jm.

95 See: https://bit.ly/3lKKzMd. 
on copyright and related rights is consistent with Art. 64 (1-2) in connection with Art. 31 (3) and Art. 2 of the Constitution of the Republic of Poland. This case concerned the scope within which a rightholder whose economic rights of copyright have been infringed may request the person who infringed those rights to remedy the loss caused: on the basis of general principles, or by payment of a sum of money corresponding to twice the amount of the appropriate fee that would have been due at the time it was sought if the rightholder had given permission for the work to be used.

The Polish Constitutional Tribunal argued inter alia-similar as to the merits but of an individual character-based on the jurisprudence of CJ EU. PCT accented that the judgment of the Court of Justice of European Union of 25 January 2017 had been given (Stowarzyszenie 'Oławska Telewizja Kablowa' w Oławie v Stowarzyszenie Filmowców Polskich w Warszawie; C-367/15 ${ }^{96}$ ) and directly influenced the judging of the domestic case. CJ EU previously ruled-based on the aim of the legislator-that Art. 13 of Directive 2004/48/EC of the European Parliament and of the Council of 29 April 2004 on the enforcement of intellectual property rights must be interpreted as not precluding national legislation under which the holder of an intellectual property right that has been infringed may demand from the person who has infringed that right either compensation for the damage that he has suffered (taking account of all the appropriate aspects of the particular case), or-without him having to prove the actual loss-payment of a sum corresponding to twice the appropriate fee that would have been due if permission had been given for the work concerned to be used. This ruling of EU Tribunal was de facto positively evaluated and adopted as more general solution (a minori ad maius), as well as the element of reasoning presented by Polish Constitutional Tribunal.

\subsubsection{Procedural civil law}

a. PCT judgment of 22 September 2015 and ECtHR case Paykar Yev Haghtanak Ltd v. Armenia of 20 December 2007 (reopening a domestic proceeding after judgment of European Court)

In the judgment of 22 September 2015 (Ref. No. SK 21/14), ${ }^{97}$ the Tribunal ruled on Art. 408 of Civil Procedure Code of 17.11.1964 to the extent of stating that, five years after the judgment becomes final, it is not possible to reopen civil proceedings (revision of a final and non-appealable judgment) due to violation of Art. 6 (1) of the European Convention. It was judged that this provision is partly inconsistent with Art. 77 (2) in connection with Art. 45 (1) of the Constitution of the Republic of Poland.

This case is an example not only in national jurisprudence and interpretation of the constitution of drawing from the models of interpretation adopted by international tribunals (here: ECtHR) regarding the interpreting of convention standards, but also an example of assessing statutory solutions constituting a 'bridge' between 
the judgment of an international tribunal and the assurance of its general consequences for the future in a given country.

The complainant presented the opinion that the five-year time limit for the reopening of civil proceedings in Polish law would close the court to protecting her rights if the grounds for reopening were to result from a judgment of the European Court. Proceedings before such a tribunal are long and drawn out and do not necessarily end within five years of the conclusion of the domestic proceedings. Finally, the Constitutional Tribunal evaluated this solution as a disproportionate in the strict sense.

In the reasoning and argumentation, the European jurisprudence was recalled, in particular the judgment of the Court (Third Section) of 20 December 2007 (Paykar Yev Haghtanak Ltd v. Armenia; application no. 21638/0398). In the justification of the Polish Tribunal's decision, an important reference was expressly made to the following fragment: 'The Court notes in this connection that Art. 241.1 of the CCP allows the reopening of the domestic proceedings if the Court has found a violation of the Convention or its Protocols (see para. 25). The Court is in any event of the view that the most appropriate form of redress in cases where an applicant was denied access to court in breach of Art. $6 \S 1$ of the Convention would, as a rule, be to reopen the proceedings in due course and re-examine the case in keeping with all the requirements of a fair trial' (para. 58). This did strengthen the argumentation of domestic tribunal, whichreiterated that the right to a court, of which the right of access constitutes one aspect, is not absolute but may be subject to limitations. Nevertheless, the limitations applied-taking into consideration the contextual interpretation-must not restrict the access left to the individual in such a way or to such an extent that the very essence of the right is impaired. Furthermore, a limitation would not be compatible with Art. $6 \S 1$ if it did not pursue a legitimate aim and if there is not a reasonable relationship of proportionality between the means employed and the aim sought to be achieved.

\section{b. PCT judgment of 8 November 2016 and ECtHR case Helmers v. Sweden of 29 October} 1991 (binding character of legal assessment and indications of the second instance court)

Another provision of general character within the civil procedure was the matter of the judgment of the Constitutional Tribunal of 8 November 2016 (Ref. No. P 126/15). ${ }^{99}$ It was judged that Art. $386 \S 6$ of the Code of Civil Procedure of 17.11.1964 is consistent with Art. 45 (1) and Art. 178 (1) to the extent that the legal assessment and indications as to further proceedings expressed in the justification of the judgment of the second instance court shall be binding on the court of first instance to which the case was referred. ${ }^{100}$

98 See: https://bit.ly/3lEFll4.

99 See: https://bit.ly/3AsndAP.

100 The given solution was evaluated as eliminating the risk of excessive length of the trial, caused by the fact that the court of first instance, which does not agree with the appeal decision, will issue a decision similar to the annulled one, and this decision will also be revoked in the future by the court of second instance after another appeal. 
The Tribunal expressly stated that Art. 45 (1) of Polish Constitution takes into account the content of Art. 6 (1) of the Convention (the right to have a case examined by an independent court). Additionally, the jurisprudence of European Court was reported with the following conclusion strengthening the final decision: It did not prejudge the model of civil proceedings, including the model of appeal and even relations between the decisions of courts of different instances in the same case.

It was highlighted that application of Art. 6 (1) in relation to proceedings before courts of appeal depends on the particular nature of the proceedings in question. It was also stressed that the manner of application of Art. 6 to proceedings before courts of appeal depends on the special features of the proceedings involved; account must be taken of the entirety of the proceedings in the domestic legal order and of the role of the appellate court therein. These conclusions were substantiated by the theses of the judgment of European Court of 29 October 1991, Helmers v. Sweden (Application no. 11826/85 ${ }^{101}$ ). Hence, the last ruling directly influenced the way of interpretation of the control template, i.e. Art. 45 of Polish Constitution.

\section{c. PCT judgment of 11 July 2018 and ECtHR case Levages Prestations Services $v$.} France of 23 October 1996 (formal components of cassation)

By its judgment of 11 November 2018 (Ref. No. SK 3/17 ${ }^{102}$ ), the Constitutional Tribunal evaluated the core components of cassation in the context of civil proceedings. It adjudicated that Art. $398^{6}(2-3)$ in conjunction with Art. $398^{4}(1,3)$, in conjunction with Art. 13(2) of the Civil Procedure Code of 17.11.1964 is consistent with Art. 45(1) in conjunction with Art. 2 and Art. 31(3) of the Constitution of the Republic of Poland. ${ }^{103}$ The Tribunal emphasized that what constitutes a protected value that justifies the legislator's adoption of such a model of a cassation appeal (which also implies the division of defects into those that are barred from being rectified and those that are subject to elimination in restructuring proceedings) is the protection of certainty and security of legal transactions. Proceedings before the Supreme Court concern legally effective rulings. The possibility of revoking such rulings because of a public interest will always result in a state of uncertainty as to the situation determined by such a ruling. ${ }^{104}$

101 See: https://bit.ly/3klhjvU.

102 See: https://bit.ly/3lAJqqi.

103 As regards the pace of proceedings at this stage, a call for the elimination of any deficiencies concerning core components of a cassation appeal within the same (one-week) time-limit would not prolong relevant proceedings. Hence, the pace of proceedings does not justify shaping requirements as to the core components of cassation appeals. Consequently, the said pace does not justify depriving parties of the possibility to supplement the aforementioned deficiencies in the context of proceedings on restructuring a debtor's liabilities (hereinafter: restructuring proceedings).

104 The said possibility will also always interfere with the principle of certainty and security of legal transactions. Proceedings on cassation appeals constitute proceedings on extraordinary means of appeal-and are not third-instance proceedings, where, until the completion of all the stages of those proceedings, parties to the proceedings must take into account the possibility that the rulings delivered by the courts of lower instances in a given case may be revoked. 
The Tribunal added that all subjects of legal rights and obligations whose legal and actual situations were shaped by a legally effective ruling should act in confidence as to the irrevocability of those determinations. In the event a cassation appeal is filed by the adversary party, the subjects of legal rights and obligations should have the possibility of predicting if there are any real chances of revoking such a ruling. ${ }^{105}$ The Tribunal stated also that a different way of determining the effects of failure to include core components in a cassation appeal and the categorization of such deficiencies as formal defects subject to supplementation in restructuring proceedings would actually lead to a complete change of their nature. However, such considerable interference with the legislator's decision is not justified in the context of the present case. In the legal doctrine and the jurisprudence of courts, it is highlighted that core components constitute mandatory elements that make up an appeal and determine that a given submission by a party is a cassation appeal. Thus, core components determine the essence of a cassation appeal. ${ }^{106}$

The reasoning of the European Court adopted in judgment of 23 October 1996, Levages Prestations Services v. France (application no. 21920/93 ${ }^{107}$ ), was of great importance for such an understanding of the constitutional template of control in the national tribunal's jurisprudence, and thus for the abovementioned decision, it was indirectly taken into consideration ( $\S \S 44-48$ ) via the reasoning in the recalled earlier judgments given by the Tribunal. As to the formalism-quite legitimately the conditions of admissibility of a cassation appeal may be more formal and limited than in the case of a normal appeal. Taking into account the special role played by the court of cassation, the procedure used by that court may be more formal, especially when the proceedings before the court of cassation take place after the case has been examined by a court of first instance and then by a court of appeal-each of them having a full range of jurisdiction. It also noted the special nature of the role of the cassation, which is limited to examining whether the law has been applied correctly.

105 The lack of formal requirements as to the content and form of a cassation appeal together with serious consequences of failing to meet them would constitute far-reaching interference with the principle of the protection of legal transactions. This would enhance the lack of certainty as to a situation shaped by a legally effective ruling. The necessity to ensure the certainty and security of legal transactions in a democratic state constitutes sufficient justification for introducing limitations to the right to a fair trial within the scope of shaping a procedure together with the serious effects of failure to meet the requirements of a cassation appeal.

106 Additionally, the lack of any of the core components entails that a given means of appeal constitutes a cassation appeal and hence the said deficiencies (primary deficiencies) are subject to elimination. The Tribunal emphasized that the high degree of formalization of cassation appeals is alleviated by the requirement that a cassation appeal be drafted by an advocate or a legal adviser. The requirement that a cassation appeal should comprise all its core components is not impossible to be met by a professional attorney. The incorrect drafting of a cassation appeal which consists in failing to meet the relevant requirements as to its core components may not be an argument for the change of the character of those elements and for the treatment of every submission as a cassation complaint.

107 See: https://bit.ly/3zpgRRA. 
d. PCT judgment of 17 May 2016 and ECtHR case Podbielski and PPU Polpure v. Poland of 26 July 2005 (costs of court procedure)

The next three discussed judgments of Polish Constitutional Court regard the issues of costs of proceedings, in particular the amount and its reimbursement, as well as the general issue of access to the court.

With the judgment delivered on 17 May 2016 (Ref. No. SK 37/14), ${ }^{108}$ the Tribunal stated that: 'The exemption of a losing party by a court from the obligation to reimburse the legal costs of a winning party in particularly justified instances, without burdening the State Treasury with the said costs, does not infringe the right to a fair trial, as regards a properly devised court procedure that complies with the principles of justice'. The Constitutional Tribunal adjudicated that Art. 102 of the Civil Procedure Code of 17.11.1964, insofar as it does not impose on the State Treasury the obligation to reimburse the legal costs of a winning party that were not adjudged to be paid by a losing party, is consistent with Art. 45(1) of the Constitution. Art. 102 was evaluated as constituting a purposeful departure, justified by the principles of equity, from the principle of liability for the outcome of a trial. According to the Tribunal, it is necessary to have a certain safety valve, i.e. in particularly justified instances, the possibility that a court may lift the obligation of a losing party to reimburse the legal costs of a winning party. ${ }^{109}$

In the opinion of the Constitutional Tribunal, the challenged Art. 102 of the Civil Procedure Code constitutes a justified exception to the principle of liability for the outcome of a trial, and it does not infringe a component of the constitutional right to a fair trial, namely the right to a proper court procedure that complies with the principles of justice. Art. 102 is thus a proper example of a departure-justified by particular circumstances of a case-from the principle of liability for the outcome of a trial. ${ }^{110}$

The Tribunal added that the principle of liability for the outcome of a trial is not, and should not, be absolute in character. There is no doubt that the legislator ought to provide for exceptions to that rule, such as the challenged Art. 102, that comply with the principle of equity. For this reason, it ought to be deemed that the challenged Art. 102 of the Civil Procedure Code not only causes no violation of a proper court procedure, which constitutes a component of the constitutional right to

108 See: https://bit.ly/3nO98u8.

109 Courts apply Art. 102 of code only by way of an exception, and the catalogue of recurring instances regarded as particularly justified is directly linked with the facts of a given case, and not merely with the financial situation of a losing party (as in the case in the context of which the constitutional complaint was submitted, where an allegation had been put forward effectively about the expiry of the claims of the petitioner, i.e. the losing party).

110 It was pointed also out that, in the consistent domestic jurisprudence, the right to a fair trial has been linked with the principle of payment for the administration of justice. This does not entail that the Tribunal departs from the view presented in its jurisprudence that, as a rule, legal costs should be adjudged to a losing party. 
a fair trial, but actually manifests the conformity of said procedure to the principle of justice. ${ }^{111}$

The arguments relating to reasoning when judging this case were presented by the European Court (Fourth Section) judgment of 26 July 2005, Podbielski and PPU Polpure v. Poland (application no. 39199/98). The following ECtHR statements were taken into consideration by the Polish Constitutional Court when shaping the normative content of the applied standard of control: 'In the present case the applicant had to desist from pursuing his case before civil courts because his company was unable to pay the court fee (...); which it had been required to pay for proceeding with the appeal. It is true that no right to appeal in civil cases can be inferred from the Convention and that, given the nature of appeal proceedings and the fact that a person has already had his case heard before the first-instance court, the State would in principle be allowed to put even strict limitations on access to a court of appeal. It is also true that in the Tolstoy-Miloslavsky v. the United Kingdom case (application 18139/91), ${ }^{112}$ the Court found that the requirement to secure a significant sum for the anticipated legal costs of the applicant's opponent in appellate proceedings had pursued a 'legitimate aim', especially given the poor prospects of success in the applicant's appeal. It also attached 'great weight' to the fact that the case had been heard for 40 days at first instance and, in that context, stressed that in cases where access to a court was concerned, the entirety of the proceedings had to be taken into account (paras. 61-67 of this case). However, restrictions that are of a purely financial nature and that, as in the present case, are completely unrelated to the merits of an appeal or its prospects of success, should be subject to a particularly rigorous scrutiny from the point of view of the interests of justice (paras. 63-64 above)'. ${ }^{113}$

111 The Tribunal found it necessary to emphasize that, from the point of view of a proper court procedure that is consistent with the principle of justice, it is vital that the principle of equity arising from Art. 102 of the Civil Procedure Code would be applied by way of an except and would not become a measure within the scope of the so-called 'poor law'. If this was the direction in which the jurisprudence of courts was headed, as regards complementing the content of the term 'particular justified instances', lacking sufficient specificity, as used in Art. 102 of the code, then the allegation raised in this constitutional complaint should be evaluated differently. Indeed, what we would deal with would not be the principle of equity - which permits a court to determine the issue of legal costs in a different way than in accordance with the principle of basic liability for the outcome of a trial-but actually the legal institution of 'poor law'.

112 See: https://bit.ly/3nQ4MCE.

113 Additionally the following fragment should be pointed out:

'66. The Court notes that, indeed, the courts at several instances heard Mr. Podbielski's case and that, eventually, the fee for lodging his company's appeal of 29 November 1996 was significantly reduced (...). Yet, in contrast to the Tolstoy-Miloslavsky case, the money that the applicant was obliged to secure did not serve the interests of protecting the other party against irrecoverable legal costs. Nor did it constitute a financial barrier protecting the system of justice against an unmeritorious appeal by the applicant. Indeed, the principal aim seems to have been the State's interest in deriving income from court fees in civil cases'. 
Also in this case, the interpretation presented earlier by the European court was used by the national tribunal to strengthen the argumentation explaining the constitutional decision taken.

The Tribunal deemed that it was necessary to underline that the constitutional standard of the right to a fair trial-as provided for in Art. 45(1) of the Constitution in fact interpreted in line with ECtHR standards-does not require free-of-charge court proceedings where the State Treasury covers the whole financial burden of the pursuit of claims by parties before courts. Therefore, the legislator may-by respecting the principle of liability for the outcome of a trial, which is regarded in the jurisprudence of the Constitutional Tribunal as basic with regard to legal costsdetermine rules for covering legal costs by parties to proceedings, taking account of certain axiological and functional considerations. ${ }^{114}$

e. PCT judgment of 4 April 2017 and ECtHR case Tiemann versus France and Germany of 27 April 2000 (costs of court procedure)

Then, in the judgment of 4 April 2017 (Ref. No. P 56/14), ${ }^{115}$ the Constitutional Tribunal heard a case on exemption from costs and on court-appointed legal representation. It was judged that the legal obligation (imposed on legal entities) to prove the lack of sufficient means to cover, respectively, legal costs as well as the costs of legal representation by an advocate or a legal adviser is consistent with the Constitution.

The Tribunal adjudicated that Art. 117(3) of the Civil Procedure Code of 17.11.1964, insofar as it burdens legal entities with the legal obligation to prove their lack of sufficient means to cover the costs of legal representation by an advocate or a legal adviser as well as Art. 103 of the Act of 28.6.2005 on legal costs in civil cases, insofar as it burdens legal entities with the legal obligation to prove their lack of sufficient means to cover legal costs, are consistent with Art. 45(1) and Art. 32(1) of the Constitution.

The Tribunal indicated that the court's role is not to substitute a party in the fulfilment of its evidentiary obligation; nor is it to show in what way the said party is to prove its statements. Moreover, the possibility that the court admits evidence which has not been indicated by parties does not mean that the court is obliged to act in the event of the inaction of a party; the fact that the court admits evidence that has not been indicated by the party does not exempt the party from the necessity to take initiative, present true statements, and provide evidentiary submissions in support thereof. The principle of equality before the law prescribes the same

114 The Tribunal held also that, in the light of the constitutional right to a fair trial, there is no direct correlation between the court's exemption of a losing party from the obligation to reimburse legal costs and the obligation of the State Treasury to reimburse legal costs. Such a solution could be justified only, and exclusively, in a situation where the assumption about free-of-charge proceedings is adopted together with the principle of liability for the outcome of a trial, namely where a winning party would always have to be reimbursed for its legal costs, either by a losing party, or by the State Treasury, even if this breached the principle of equity.

115 See: https://bit.ly/3Ewan7c. 
treatment with regard to similar subjects of rights and obligations, but it does not prohibit the adoption of different legal solutions with regard to the subjects that differ in respect of certain essential characteristics. ${ }^{116}$

The decision of EHCR (Fourth Section) of 27 April 2000, Tiemann versus France and Germany (application no. 47457/99, 47458/9917) has such an effect of constitutional control and was recalled. The European Court reiterated that it was not its task to substitute its own assessment of the facts and the evidence for that of the national courts, but to establish whether the evidence was presented in such a way as to guarantee a fair trial. In addition, Art. 6 (1) of the European Convention does not lay down any rules on the admissibility or probative value of evidence or on the burden of proof, which are essentially a matter for domestic law. This theological statement influenced the interpretation of the domestic constitutional standard. The constitutional issue in the case was the question whether, imposed on legal entities, the legal obligation to prove the lack of sufficient means to cover, respectively, legal costs as well as the costs of legal representation by an advocate or a legal adviser is consistent with the right to a fair trial as regards a properly devised court procedure and the principle of equality before law.

This led to the final detailed conclusion that applicants applying for exemption from legal costs and for the appointment of professional legal representation may prove that they lack sufficient means for that purpose by submitting any available evidence. However, the applicants may not limit themselves to filing a statement about the lack of such means or to indicating factual circumstances without presenting any appropriate documents. ${ }^{118}$

\section{f. PCT judgment of 21 June 2017 and ECtHR case Weissman and Others v. Romania} of 24 May 2006 (costs of court procedure)

The terms of determining rates for the services of advocates as well as the State Treasury's payment of the costs of unpaid court-appointed legal representation

116 It was also stated that individuals and legal entities are subjects of rights and obligations that share no common essential characteristic that would justify the necessity to treat them equally as regards the legal obligation to prove the lack of sufficient means to cover legal costs and the costs of legal representation by an advocate or a legal adviser.

117 See: https://bit.ly/2XwtNYy.

118 PCJ accented that the type of documents that make it possible to determine the financial situation of the applicants what is vital in the course of considering such applications. The type of the documents depends on the kind and character of a legal entity applying for the aforementioned exemption and it should be adjusted to the said entity. It was also added, that proving the lack of sufficient means falls within the scope of the evidentiary procedure. It is the legal entity's obligation not only to apply the procedure, but also to select evidentiary means. The type of evidentiary means should, in every case, be adjusted not only to a specific entity, but also to the current legal and factual situation-there should be a different way of proving the aforementioned lack of sufficient means by a capital company, a state-owned company or a local self-government legal entity. Were the legislator to enumerate all possible types of evidence that could be presented to determine the lack of sufficient means to cover the costs of proceedings or the costs of professional representation, this might prove excessive as well as could hinder a court's assessment of a specific situation. 
in civil proceedings were the subject of the case judged on 21 June 2017 (Ref. No. SK 35/15). ${ }^{119}$ The Constitutional Tribunal stated that: 'The choice of a method for determining the minimum rate for legal representation falls within the remit of the legislator, who-within the limits of the constitutional order-enjoys considerable regulatory discretion'. The Tribunal adjudicated that $\S 12(1)(1)$ of the Minister of Justice Regulation of 28.9.2002 as regards rates for the services of advocates as well as the State Treasury's payment of the costs of unpaid courtappointed legal representation-insofar as it specifies the minimum rate for the services of an advocate in a case concerning compensation for the ineffective termination of an employment agreement-is consistent with Art. 45(1) in conjunction with Art. 31(3) of the Constitution. ${ }^{120}$ In the view of the complainant, the challenged provision makes it impossible to take account of actual work carried out by a lawyer and costs related thereto that are incurred by a party represented by the lawyer, and thus the provision rules out the possibility that the party will receive the fullest compensation for the necessary costs rightly incurred in the course of court proceedings. ${ }^{121}$

The Constitutional Tribunal disagreed with the complainant's stance that the non-inclusion of all incurred costs of legal representation in the category of the indispensable costs of the trial of a party represented by a chosen advocate disproportionately infringed the right to a fair trial. Indeed-the again interpreted-Art. 45(1) of the Constitution does not guarantee the reimbursement of any costs incurred by a party pursuing its claims or defending its rights. In its opinion, what may not be derived, in particular, from the said provision is the court's obligation to order the reimbursement of the costs of proceedings in the amount specified in an agreement entered into by a party winning a trial and its lawyer. Indeed, when adjudicating upon the costs of proceedings, the court is not bound by the provisions of an agreement between an advocate and his/her client in which the parties to the agreement may freely formulate the provisions of the agreement and a rate charged by the said lawyer. ${ }^{122}$

119 See: https://bit.ly/31Dzj45.

120 The issue presented in the aforementioned constitutional complaint was more general and concerned the calculation of the costs of court proceedings. The doubts of the complainant concerned the terms of allocating costs among the parties of proceedings from the point of view of a breach of the right to a fair trial. The complainant challenged a legal norm derived from § 12(1)(1) of the Regulation, in accordance with the minimum rate for the services of an advocate in a case concerning the ineffective termination of an employment agreement.

121 According to the complainant, the distribution of the costs of a trial in the way that the winning party may not receive the reimbursement of the costs of legal representation-in the amount calculated proportionately to the value of the subject of the dispute-incurred by paying the remuneration of a chosen advocate, constitutes an economic barrier that limits access to court.

122 In the reasoning it was stressed that when determining an amount of payment for the services of an advocate for legal representation, a court takes account of the degree of complexity of a case, the workload of the advocate and contribution to the explanation and determination of the case; the court assesses this within the limits of maximum rates specified in a relevant normative act concerning advocates' fees. 
The Tribunal pointed also out that in cases concerning employees-due to the principle that employees have a somewhat privileged status, which arises from the assumption about their significantly weaker economic position in relation to their employers-minimum rates (which also affect maximum rates), in situations where employees lose at trials, are aimed at protecting the property interests of employees and preventing situations where they will give up on pursuing their claims, fearing high (or even exorbitant) costs of the legal representation of their opponent that they would have to reimburse if they lost at trial.

This reasoning is influenced by the arguments presented in the European Court's judgment of 24 May 2006, Weissman and Others v. Romania (application no. $\left.63945 / 00^{123}\right)$. Notwithstanding the margin of appreciation enjoyed by the State in this area, the Court emphasizes that a restriction on access to a court is only compatible with Art. $6 \S 1$ if it pursues a legitimate aim and if there is a reasonable degree of proportionality between the means used and the aim pursued. ${ }^{124}$

Delivering its ruling, the Polish Constitutional Tribunal took into consideration para. 42 of the written reasoning of this judgment, which meant accenting the role of following elements: a restriction imposed at an initial stage of the proceedings, disproportion, and impairment of the very essence of the right of access to a court. Finally, in the Tribunal's view, the limitation of rates-explicitly arising from Art. 98(4) of the Civil Procedure Code-is justified by the need to predict the financial consequences of a trial as well as to protect the losing party against the winning party's excessive estimation of its advocate's fees (which concerns to an equal extent an employee as well as an employer, in cases pertaining to an appeal against the termination of an employment agreement). ${ }^{125}$

123 See: https://bit.ly/3zjMV9u.

124 In particular, bearing in mind the principle that the Convention is intended to guarantee not rights that are theoretical or illusory but rights that are practical and effective, the Court reiterates that the amount of the fees, assessed in the light of the particular circumstances of a given case, including the applicant's ability to pay them and the phase of the proceedings at which that restriction has been imposed, are factors which are material in determining whether or not a person enjoyed his or her right of access to a court or whether, on account of the amount of fees payable, the very essence of the right of access to a court has been impaired.

125 The Constitutional Tribunal stated also that the choice of a method for determining the minimum rate for legal representation (whether chosen by a party or appointed by a court) falls within the remit of the legislator, who-within the limits of the constitutional order-enjoys considerable regulatory discretion. The adoption of a fixed rate or a rate that is proportionate to the value of the subject of a dispute or allegation does not, in itself, determine the result of the test of constitutionality, as the decisive factor is not the set rate of remuneration (which translates into an amount of payment ordered to reimburse the costs of proceedings), but the impact of the entire 'regulation of fees' on the rights and freedoms guaranteed by the Constitution. Therefore, the Tribunal held that the legislator may devise a mechanism for calculating the minimum rate for legal representation (also the maximum rate) in various ways, by focusing on certain functions of the costs of proceedings in a given category of cases, by appropriately weighing up the public and private interest, as well as by implementing significant-from the point of view of the legislator's policy—rights or values. 
g. PCT judgment of 14 January 2014 and ECtHR case Airey v. Ireland of 9 October 1979 (costs of questioning the public procurement)

The other important cases concerning Act of 28.6.2005 on Court Costs in Civil Cases related to the detailed issue of judicial questioning under public procurement. The first judgment of 14 January 2014 (Ref. No. SK 25/11) ${ }^{126}$ concerned the method of calculating the costs of a proceeding. It was judged that Art. 34 (2) of this Act-insofar as it requires the payment of a relevant court fee for filing a complaint against a decision of the Polish National Appeal Chamber in an amount that may make it impossible for a party to resort to this legal remedy and for the case to be considered by a competent common court-is consistent with Art. 45(1) in conjunction with: Art. 31(3), Art. 77(2), and Art. 78 of the Constitution.

Among the European Court's rulings taken into consideration by the Polish Tribunal was the judgment of 9 October 1979, Airey v. Ireland (application no. 6289/73 ${ }^{127}$ ). The European Court stated that the Convention is intended to guarantee, not rights that are theoretical or illusory, but rights that are practical and effective (par. 24).

h. PCT judgment of 15 April 2014 and ECtHR case Aït-Mouhoub v. France of 28 October 1998 (costs of questioning the public procurement)

The next judgment of the Polish Constitutional Tribunal in this matter was given on 15 April 2014 (Ref. No. SK 12/13). ${ }^{128}$ In this procedure the Tribunal stated that Art. 34(2) of the Act of 28.6.2005 on Court Costs in Civil Cases in inconsistent with Art. 45(1) in conjunction with Art. 31(3), Art. 77(2), and Art. 78 of the Constitution. The opinion was expressed that the legislator could achieve the same goals by limiting access to court to a lesser extent, and thus adopt a regulation that was less severe for subjects of constitutional rights and freedoms.

The argumentation from judgment of Court of 28 October 1998, Aït-Mouhoub v. France (application no. 22924/93 ${ }^{129}$ ) was expressly recalled by the national constitutional court. In its reasoning it can be read that the 'right to a court', of which the right of access constitutes one aspect, is not absolute but may be subject to limitations permitted by implication. However, these limitations must not restrict or reduce a person's access in such a way or to such an extent that the very essence of the right is impaired, and they will not be compatible with Art. 6 (1) if they do not pursue a legitimate aim or if there is not a reasonable relationship of proportionality between the means employed and the aim sought to be achieved.

This way of understanding the provisions of the Convention-similarly to the previously discussed private law provisions-influenced the interpretation of the content of the national constitutional standard of control by strengthening the given reasoning. 
i. PCT judgment of 2 December 2020 and ECtHR case Teltronic-CATV v. Poland of 10 January 2006 (costs of questioning the public procurement)

The third in this series of judgments was delivered by the Polish Constitutional Tribunal on 2 December 2020 (Ref. No. SK 9/17), ${ }^{130}$ adjudicating as follows: Art. 34(1) of the Act of 28.7.2005 on Court Costs in Civil Cases-due to the fact that it introduces a disproportionately high fixed fee-is inconsistent with Art. 45(1) in conjunction with Art. 31(3) and Art. 77(2) of the Constitution. The Tribunal found that this provision introduces a disproportionately high fixed fee.

The jurisprudence of the European Court was directly referred to in support of this decision, in particular the judgment of 10 January 2006, Teltronic-CATV v. Poland (application no. 48140/99131). By the interpretation of Art. 45 of the Constitution it was recalled in the Court's reasoning that Art. 6 (1) secures to everyone the right to have any claim relating to his civil rights and obligations brought before a court or tribunal. In this way, that provision embodies the 'right to a court', of which the right of access, that is, the right to institute proceedings before a court in civil matters, constitutes one aspect only; however, it is an aspect that makes it in fact possible to benefit from the further guarantees laid down in Art. $6(1) .{ }^{132}$

j. PCT judgment of 16 November 2011 and ECtHR case Bosphorus Hava Yollari Turizm ve Ticaret Anonim Şirketi v. Ireland of 30 June 2005 (participation in civil procedure)

On 16 November 2011 the full bench of Constitutional Tribunal (Ref. No. SK 45/09) ruled on exclusion of a debtor from proceedings before the court of first instance, in the case where the proceedings regarded the enforceability of a ruling issued by a court from another EU Member State. The Tribunal adjudicated that Art. 41, second sentence, of the Council Regulation (EC) No 44/2001 of 22.12.2000 on jurisdiction and the recognition and enforcement of judgments in civil and commercial matters was consistent with Art. 45(1) as well as Art. 32(1) in conjunction with Art. 45(1) of the Constitution. The Constitutional Tribunal stated that a fair judicial procedure should ensure that parties enjoyed procedural rights that were relevant to the subject of pending proceedings. The requirement of a fair trial implies that the principles of the trial are adjusted to the special character of particular cases under examination. Constitutional guarantees related to the right to a fair trial may not be regarded as a requirement to provide in every type of proceedings the same set of

130 See: https://bit.ly/3AqRVui.

131 See: https://bit.ly/3zvTeHe.

132 The requirement to pay fees to civil courts in connection with claims or appeals cannot be regarded as a restriction on the right of access to a court that is incompatible per se. However, the amount of the fees assessed in the light of the particular circumstances of a given case, including the applicant's ability to pay them, and the phase of the proceedings at which that restriction has been imposed, are factors that are material in determining whether or not a person enjoyed that right of access and had 'hearing by tribunal'. 
procedural instruments that would uniformly specify the position of the parties to proceedings and the scope of procedural measures available to them.

This case is an example not only of the impact of the interpretation adopted earlier in the jurisprudence of an international court on the way in which a domestic tribunal would interpret it later. What is more interesting, this case is an example of a very specialized legal argumentation that consists in an attempt to transfer the ECtHR acquis on the relationship between the content of EU law and standards resulting from the EctHR to the legal shaping of mutual relations among other fundamental normative sets, i.e. between EU law and the constitutional standards of national law.

Examining the constitutionality of the challenged provisions, PCT stated inter alia: 'Likewise, in the jurisprudence of the European Court of Human Rights, there is a presumption that EU law and the Court of Justice ensure the protection of human rights at a level that is equivalent to the level of protection required by the European Convention for the Protection of Human Rights and Fundamental Freedoms. Therefore, the actions of the EU Member States are consistent with the Convention as long as the European Union protects human rights, by applying - for that purposeappropriate guarantees of protection as well as control mechanisms that are at least equivalent to those guaranteed by the Convention. What follows from the above is that the European Court of Human Rights is competent, only in exceptional cases, to assess whether actions, or lack thereof, on the part of the EU bodies and institutions are consistent with the Convention; namely, i.e. when the presumption of equivalent legal protection is undermined, and the protection of human rights at the EU level is "manifestly deficient"'.

Similar reasoning can be found in the earlier European Court judgment of 30 June 2005, Bosphorus Hava Yollari Turizm ve Ticaret Anonim Şirketi v. Ireland (application no. 45036/98). ${ }^{133}$ The European Court in this case refused to review an EC regulation implementing a UN Security Council resolution, although the content of the EC regulation was restrictive of the applicant's property right. The decision was based on the presumption that EU law was not breached, as the European Court held that the system of safeguarding fundamental rights guaranteed at the EC level was comparable to that provided by the Convention.

In the opinion of the Polish Constitutional Tribunal, there are premises for adopting an analogical approach when examining the constitutionality of EU law in Poland. What justifies an analogical approach to that taken by other courts are the following aforementioned arguments: the great significance of fundamental rights in the EU legal order, the constitutional principle of favorable predisposition of the Republic of Poland toward the process of European integration, and the Treaty principle of loyalty of the Member States toward the Union. 


\subsubsection{Bioethics and medical law}

a. PCT judgment of 11 October 2011 and EctHR case $X$ and $Y v$. Netherlands of 26 March 1985 (consent to medical treatment granted by a minor)

By its judgment of 11 October 2011 (K 16/10), ${ }^{134}$ the Polish Constitutional Tribunal considered the constitutionality of the provisions of health-care services that grant underage patients the right to participate in decision-making as regards the course of medical treatment after they have reached the age of 16. The Tribunal had to examine whether the formal criterion (the age) used by the legislator does actually restrict the fundamental subjective rights of underage patients, enshrined in the Constitution, especially of personal inviolability and security, respect the degree of maturity of a child as well as his freedom of conscience and belief and his convictions, and the right to legal protection of his private and family life.

The Tribunal assessed the constitutionality of the regulations. According to the judgment, the Constitution does not require that the views of the minor considering health-care matters should have any direct legal effects. They also contain no detailed information about the minimum age at which the views and actions of the child should trigger legal consequences.

In this judgment the Tribunal applied an external argument derived from the European Convention for the Protection of Human Rights and Fundamental Freedoms. What is more, the Tribunal referred to the domestic constitutional system, in particular relevant previous decisions of the Constitutional Court and arguments based on the jurisprudence of the Polish Supreme Court.

The Tribunal considered the infringement of the personal liberty and personal inviolability of a minor under 16 whose consent to medical treatment was omitted by the law. The mentioned liberty was understood by the Tribunal as 'the possibility of taking his/her own decisions by the individual in compliance with his/her will and making his/her own choices in public and private life that are unrestrained by other persons'.

The interpretation of freedom has been derived by the Tribunal inter alia from the ruling of the Polish Supreme Court, which-in accordance to the Art. 8 of the European Convention-in a democratic state 'is protected in a special way, including the freedom of private life and the autonomy to make choices, as one of the fundamental principles of the contemporary doctrine of human rights, which is to be particularly protected by the state'. Nevertheless, the Tribunal considered that this freedom should not be treated as an absolute value, ${ }^{135}$ even though the regulation undeniably restricts the autonomy of the patient. Hence the regulations remain within the remit of the legislator. According to the judgment, leaving the assessment of the awareness of the patient at the discretion of medical personnel assigned to carry out core health care activities (admission to hospital, a procedure, examination) could 
lead to much more serious infringements of patients' rights than those that-according to the applicant-occur in the context of currently binding provisions. ${ }^{136}$

Although the Polish Tribunal in this case did not recall by reference number any ruling of the European Court, it de facto referred to the normative content of Art. 8 of the European Convention adopted earlier in the ECtHR jurisprudence. One of the prominent cases where the European Court applied this content was the judgment of the European Court of Human Rights of 26 March 1985, X and Y v. Netherlands (application no. 8978/80). ${ }^{137}$ It was stated there that 'although the object of Art. 8 (Art. 8) is essentially that of protecting the individual against arbitrary interference by the public authorities, it does not merely compel the State to abstain from such interference: In addition to this primarily negative undertaking, there may be positive obligations inherent in an effective respect for private or family life (...). These obligations may involve the adoption of measures designed to secure respect for private life even in the sphere of the relations of individuals between themselves'. ${ }^{138}$

Such an understanding of the similar wording of the provision, which in both proceedings served as a model for review, was also used in the recitals explaining the adopted content of the national constitutional standard, and thus it was used as an argument for the decision made.

b. PCT judgment of 10 December2014 and ECtHR case Cha'are Shalom Ve Tsedek v. France of 27 June 2000 (ritual slaughter)

The judgment of the Polish Constitutional Tribunal of 10 December 2014 (Ref. No. K 52/13) ${ }^{139}$ referred to the constitutional dilemma of whether the lack of permission to subject animals to slaughter in a slaughterhouse in accordance with special methods prescribed by religious rites, as well as criminal liability for subjecting animals to such slaughter, is consistent with Art. 53(1), (2), and (5) of the Constitution in conjunction with Art. 9 of the European Convention.

The background of the case was the legislator's decision to forbid, with criminal sanctions following, the slaughter of animals in accordance with special methods prescribed by religious rites. This ban was complete and without exceptions on carrying out ritual slaughter in a slaughterhouse. The constitutional problem was the compliance with regulations ensuring the protection of freedom of religion, which may be derived not only from Polish Constitution (Art. 53), but also from the European Convention (Art. 9). According to the Tribunal, the guarantee of the freedom of religion provided in Art. 53(1) and (2) of the Constitution, comprised the carrying out of any activities (practices, rites, or rituals) that are religious in character. These

136 Consent to medical treatment granted by a minor K 16/10—shortcut.

137 See: https://bit.ly/3ApXh9f.

138 See para. 23 of the judgment.

139 See: https://bit.ly/2XH8Zht. 
also included unusual religious activities, or even those that might be unpopular with a majority of the public. ${ }^{140}$

At the same time, the Tribunal noted that freedom of religion is not an absolute value and it might be restricted. However, the restriction should be proportional. ${ }^{141}$ The legislator may introduce restrictions, but only if such restrictions were necessary for the protection of national security, public order, health, morals, or the freedoms and rights of others. None of these constitutional values forejudge the possibility of introducing an absolute ban on the ritual slaughter. The Tribunal took into account weighing the freedom of religion with public morality and indicated that there was no infringement-taking into account the support for the slaughter in Poland and consistent with the moral view of Poles on the need to strongly protect religious activities.

The Tribunal used the method of interpretation of the constitution on the basis of case law of the Constitutional Court, including its previous decisions. What is more, the Tribunal referred to the teleological interpretation through an interpretation of the preamble and axiological sources of the Constitution.

The Tribunal also showed the incompliance of the regulation forbidding ritual slaughter to Art. 9 of the European Convention. In particular, the judgment of the European Court of Human Rights of 27 June 2000, Cha'are Shalom Ve Tsedek v. France (application no. 27417/95), ${ }^{142}$ was widely mentioned in the ruling on the argumentation level. The Tribunal used the research made by European Court in this caseespecially the findings of the European Court on the method of slaughter prescribed by Judaism and required by Jewish traditions, as well as specifying the requirements that need to be met by persons authorized to perform such slaughter (with quotations of, e.g. excerpts from Jewish religion rules). The Tribunal agreed with the European Court of Human Rights that 'subjecting animals to particular methods of slaughter prescribed by religious rites so as to obtain acceptable food constitutes an element (way) of manifesting the freedom of religion and is subject to protection under Art. 9 of the Convention'. ${ }^{143}$

The case Cha'are Shalom Ve Tsedek v. France also referred to the problem of ritual slaughter in view of the freedom of religion ensured in Arts. 9 and 14 of the European Convention. The Court found 'that an ecclesiastical or religious body may, as such, exercise on behalf of its adherents the rights guaranteed by Art. 9 of the

140 See: https://bit.ly/3Ezks3j.

141 About freedom in the view of Polish Constitution see more: Podkowik, 2017, pp. 42-61, especially: 'Therefore, being a social contract, the Constitution represents resolution of conflicts of fundamental value and/or social importance. These norms, by limiting natural freedom of every human being, determine the constitutional framework for the protection of freedom as a legal position (the so-called fundamental freedom). Thus understood freedom may be subject to further, proportionate restrictions imposed by an ordinary legislator'. Ibid., pp. 60-61.

142 See: https://bit.ly/3nQEPCX.

143 About the commented judgment see also: Łętowska, Grochowski, Wiewiórowska-Domagalska, 2015, pp. 53-66. 
Convention'. Although the Court expressed the conviction that the government may establish rules regulating the practice of the ritual slaughter, it held that animal slaughter performed in accordance with the method prescribed by Judaism constitutes a rite covered by the right to manifest one's religion in observance, guaranteed in Art. 9 of the Convention.

c. PCT judgment of 23 November 2016 and ECtHR case M. v. Germany of 10 May 2010 (dealing with persons with mental disorders who constitute a threat to other persons)

The Constitutional Tribunal confirmed the compliance of almost all the regulations of the Act on Procedures for Dealing with Persons with Mental Disorders who Constitute a Threat to Other Persons' Life, Health, or Sexual Freedom with the Constitution ${ }^{144}$ in its judgment of 23 November 2016 (Ref. No. K 6/14). ${ }^{145}$ As indicated by commentators, this law 'was intended to be a remedy that provided the possibility of returning offenders who were perceived as particularly dangerous to society: Offenders against whom-on the strength of the above mentioned normative acts-a sentence of life imprisonment had not been handed down, but "merely" a penalty of 25 years' imprisonment'. ${ }^{146}$ Such offenders were placed in a center for appropriate therapeutic treatment after serving their sentence. One of many constitutional dilemmas was the compliance of the regulation with the principles of lex retro non agit and $n e$ bis in idem. ${ }^{147}$

The important part of the judgment was thus the interpretation of the above legal principles. The Tribunal referred inter alia to the decision of the European Court of Human Rights of 10 May 2010, M. v. Germany (application no. 19359/04), ${ }^{148}$ concerning the permissibility of post-penal isolation. The Tribunal used this judgment a contrario. The Tribunal pointed out that the German provisions differed from the Polish ones. The Polish procedure-in opposition to the German one-seemed similar to isolation without consent of persons with mental disease rather than penal isolation.

The Tribunal showed the aspects of the regulation that focused on therapeutic aims, with the civil procedure regulating the judgment of such cases. Isolation according to these provisions is not connected directly with the prohibited act performed by the offender.

The case M. v. Germany referred to German provisions concerning the post-penal detention of persons who pose a threat to society. The Court claimed that such provisions-in compliance with Art. 5 and Art. 7 of the European Convention-should not infringe the lex retro non agit principle. The retroactive, 'preventive' isolation in the

144 Ibid.

145 See: https://bit.ly/3zphniu.

146 See more: Bocheński, 2016, p. 633.

147 See more: e.g. Kluza, 2018, pp. 59-74.

148 See: https://bit.ly/3zqwt7a. 
applicant's case did not differ much from 'standard' penal detention. What is more, the aims of the punishment and the preventive measure seemed to be similar. The Court indicated that the German procedure concerning 'preventive isolation' is the same as a sentencing penalty, with the same courts deciding in both cases. An important reason to consider the isolation as having a penal character was the severity of sanction with its indefinite character.

d. PCT judgment of 7 October 2015 and ECtHR case Bayatyan v. Armenia of 7 July 2011 (medical conscience clause)

In the judgment of 7 October 2015 (K 12/14), ${ }^{149}$ the Polish Constitutional Tribunal examined whether Art. 39 of the Medical Profession Act violated the freedom of conscience of physicians (Art. 53 para. 1 of the Polish Constitution) in that it obliged a physician quoting the conscience clause to provide a patient with information on the actual possibility of obtaining a given service from another physician.

The Tribunal held that the freedom of conscience enables invoking the conscience clause and-as a result-ensures the right to refuse to perform an act contrary to one's conscience. ${ }^{150}$ What is more, the conscience clause allows not only refusal to provide medical treatment, but also to refuse to provide information about the possibility of obtaining such a treatment. In the judgment one may find the statement, according to which the duty to perform the conduct indirectly leads to an unacceptable ethical effect, [and] in particular [protection] from coercion to cooperate in achieving an immoral goal'. ${ }^{151}$

When reasoning, the Tribunal used the variety of methods in the judgment: from interpretation in the light of general principle (i.e. salus aegregoti suprema lex esto), through an interpretation based on the norms of other legal systems, axiological and teleological argumentation, and historical interpretation, to argumentation based on precedents of the European courts, including the abovementioned.

According to the Tribunal, that right stems directly from the concept of freedom of conscience and has been acknowledged internationally, including in the case law of the European Court of Human Rights. ${ }^{152}$ The Tribunal followed the understanding of the European Court of Human Rights of the conscience clause. Recalling the judgment of the European Court of Human Rights of 7 July 2011, Bayatyan v. Armenia (application no. 23459/03), ${ }^{153}$ the Tribunal found the 'conventional standard' according to which the democratic state should respect the interests of the individual, whose motivation was not arbitrary but religious. Accordingly, such an interest deserves protection also under the Polish Constitution.

149 See: https://bit.ly/2XqxWNH.

150 See more: Olszówka, 2019, pp. 376-377.

151 Ibid.

152 See more: Brzozowski, 2017, pp. 35-36.

153 See: https://bit.ly/2ZfZE0A. 
In the case of Bayatyan v. Armenia, the Court considered that 'the applicant's failure to report for military service was a manifestation of his religious beliefs'. These-according to Art. 9 of the European Convention-are protected, especially in reference to minorities. The Court indicated that 'pluralism, tolerance, and broadmindedness are hallmarks of a "democratic society". Although individual interests must on occasion be subordinated to those of a group, democracy does not simply mean that the views of a majority must always prevail: A balance must be achieved that ensures the fair and proper treatment of people from minorities and avoids any abuse of a dominant position'. ${ }^{154}$

\section{Statistical study of methods}

\subsection{Grammatical (textual) interpretation}

\subsubsection{Syntactic and semantic interpretation}

Grammatical interpretation plays important role in judging by the PTC and in the corresponding decisions of ECtHR and CJ EU. It is a method applied 28 times in different forms and types, in particular taking into consideration the ordinary meaning and legal professional (dogmatic) interpretation. Legal provisions, also constitutional ones, are supposed to be linguistically formulated for non-lawyers, who should be able to understand them easily.

Generally speaking, syntactic interpretation (conclusion from the elements of the structure of the sentence and their relations), semantic (lexical) interpretation (meaning of a given expression, i.e. ordinary grammatical semantic interpretation), interpretation based on professional terminology (professional interpretation from the perspective of a person experienced in a given profession), and interpretation on the basis of legal principles of legal regulations or legal branches also belong to this category.

In the discussed decisions, this interpretation was used by PCT to determine the normative content both of the constitutional standard (template) and of the controlled provisions. The literal text and the grammatical context was a part of reasoning in 10 of the presented cases. For the purpose of this study, the grammatical interpretation includes also the application of the legal (defined in a given scope of application) meaning. Of course, explicit legal meanings (relevant definitions) were taken into consideration as a method of interpretation.

PTC quite often applies semantic interpretation (12 cases) and its own previous effects of interpretation of legal expressions and recent cases ( 7 cases). It often 
happens that the principles presented in the legal doctrine are taken into account (6 cases).

\subsubsection{Legal principles}

Generally speaking, reference to the codified principles of law occurs in six of the discussed decisions. It plays an important role in argumentation and reasoning. The principles are both of a general character (referring to whole legal system) and closely connected with the branches of law invoked by the PCT in its decisions.

The most important are the following: the effectiveness of access to court (in cases regarding the civil procedure) and special principles: ne bis in idem, nullum crimen sine lege, and salus aegregoti suprema lex esto (connected with criminal law cases). The PCT referred to the principles common for the domestic and international legislator, and in particular to the normative content of Art. 5 and Art. 8 of the European Convention. Interesting examples of such direct references with deeper analyses are the cases $\mathrm{K} 12 / 14$ and $\mathrm{K} 54 / 13$.

The role of grammatical interpretation in the decisions of the ECtHR presented above seems also to be important. The fragments (structure) of reasoning are directly linked to the examined expressions used in the European Convention. This 'compulsory' way of judging covers all the cases, as well as a situation where previous case law exists, and the main method can be evaluated as contextual.

ECtHR in the presented cases takes into account a number of legal principles when interpreting the European Convention. Some of them, as mentioned above, are principles of international law codified in the Vienna Convention. The important legal values protected by the Council of Europe, in particular the ECHR, is combined with the doctrine of effectiveness. Since 1975 it has been applied in cases-also in all of the examined ones-regarding access to a court under Art. 6(1) of European Convention. ${ }^{155}$

The explanation may be that the interpretation of the ECHR, as an international treaty, is regulated by Art. 31 et seq. of the Vienna Convention on the Law of Treaties of 23 May 1969. The important rule of interpretation provided for by this convention states that 'the provisions of a treaty should be interpreted according to its ordinary meaning'. According to the Vienna Convention, the European Convention should be interpreted according to its object and purpose.

It may also be noted that PCT obviously applies only the Polish version of constitutional provisions, while the comparison of the different official texts (English and French) may be an argument used by ECtHR.

Legal principles existing in given branches of law (criminal, private, procedure) that were mentioned above were not so often stipulated in ECtHR decisions. The Court was oriented rather toward law in action and its practical effectiveness than 
on the principles within the branch of law (in its Latin terminology). The exception may be the ne bis is idem principle, which is internationally known and perceived similarly.

The role of general principles of law (non-explicated in legal texts) in the interpretation of fundamental rights will be presented below (see Section 3.8).

\subsection{Logical arguments}

Logical interpretation is also used in a large group of the studied cases before the PCT, and can be considered as comprising six types. The classical logical methodsargumentum a contrario, per analogiam, a maiori ad minus (inference from larger to smaller)—are de facto used, but not always mentioned directly by the judge-reporter. In many cases, the Court simply invokes the substantive effect of applying these rules and proceeds to further scrutiny rather than dealing with the formal question of naming the method of interpretation used.

The effects of the lex specialis derogat legi generali principle were mentioned by the PTC in five cases, both directly and indirectly (by drawing conclusions of the legal order 'built' in the given case by the content of lex specialis, but without showing its role in comparison to lex generali functioning in the given legal system).

In most of the justifications examined, this tended to build explicite or per analogiam to the content of the control model (standard). What is interesting is that in case K 6/14 the Tribunal used the ECtHR judgment $a$ contrario (inference from the opposite).

Another interesting example is the case P 12/09, where PCT presented an argumentum a simile, referring to similar regulations (combined with contextual interpretation).

Another interesting argumentation presented in case 45/09 should be noted, in which the relationship between the standards resulting from the ECtHR and the standards of EU law assessed from this perspective (including a special presumption of conformity as a starting point for assessment) would also be the relationship between the standards of national constitutional law and the controlled provisions of EU law. This operation can be interesting in particular from a theory of law perspective: e.g. first, analogia iuris application of a given legal approach, and, second, the presumption of the conformity of EU law with the legal standards of the European Convention. Both were applied to deliberate per analogiam a similar presumption on other levels, i.e. the conformity of EU law with national constitutional standards.

This method of interpretation was expressly used by the ECtHR in six cases.

\subsection{Systemic arguments}

Legal principles and rules constitute a system in which all legal norms have a regulatory background. This large group of studied methods, which could be described as 'systematic interpretation', comprises several specific methods of legal interpretation. 
As the most important we may list: contextual interpretation, interpretation on the basis of national statutory law, interpretation on the basis of the court's own previous case law or on the basis of the case law of ordinary courts (e.g. civil or criminal ones), and interpretation on the basis of normative acts of other domestic state organs. Their total use was estimated at 47 times.

\subsubsection{Contextual interpretation}

Contextual interpretation was identified often. It may be seen in a narrow or a broad sense. The first occurs when the constitutional court determines the meaning of a given constitutional provision on the basis of other specific constitutional provisions (e.g. comparing or according it with them). The second may be indicated when the meaning of the constitutional norm is constructed on the basis of its purpose, which is merely the result of its place in the system of the legal norms. Contextual interpretation in a narrow or broad sense plays a role in the interpretation in 28 of the abovementioned decisions.

Contextual interpretation in the narrower sense and drawing a conclusion from the placement of the provision (especially in the first chapter of the Constitution, 'Republic of Poland') can be found in three decisions.

One interesting example is case P 12/09, where PCT presented contextual interpretation (combined with argumentum a simile, referring to similar regulations).

This method was also important to determine the scope of Art. 31 of the Constitution, in particular to divide and to specify the scopes of application of the different chapters of the Polish constitution and their differing impacts on the content of fundamental rights (and more broadly, the content of constitutional standards and control templates).

Contextual interpretation, meaning that a conclusion is drawn from the placement of the provision within the full normative set of norms, was not presented directly in the abovementioned decisions of ECtHR and CJ EU. This should rather not lead to the conclusion that ECtHR does not attach any importance to the fact that fundamental rights were first included in the Convention of 1950 and then-e.g. the protection of proprietary rights-in the Additional Protocol.

The ECtHR did not apply a derogation formula in the 30 decisions presented above.

\subsubsection{Interpretation on the basis of domestic statutory law}

The interpretation on the basis of domestic statutory law plays a double role in the studied activity of the PTC. First, the constitutional court pays attention to the real (law in action) statutory law, i.e. to its content functioning in judiciary practice. Second, PTC may refer to the explanatory reports on drafts of statutory law and assume their interpretations of law. 
Of course, the interpretation on the basis of statutory law (a lower-level source within the legal system) is in general irrelevant in this second situation. The constitutional principles, standards, and control templates have their own autonomous content (especially autonomous in relation to the lower-level provisions of national law). However, it may play a supplementary role, because the effect of the autonomous interpretation of constitution may lead (there is of course no prohibition) to the same substantive effects as the interpretation of similar provisions 'repeated' by the national legislator in other sources of law.

National legal systems are evaluated by ECtHR from a practical point of viewi.e. the real content of law in action and the issue of effectiveness. It plays an important role in the cases, where the context of the 'statutory' nature of the restriction of a specific fundamental right is discussed.

Taking the national legislation into account is of course needed when the 'margin of appreciation' provided for in some of the ECtHR provisions is presented and evaluated in a given case.

\subsubsection{Interpretation on the basis on previous jurisprudence of the constitutional court or ECtHR}

In all (30) of the studied cases of reasoning presented by PCT, the chosen cases referred in detail to this method of interpretation. The domestic legal tradition simply consists of previous rulings. This tradition is constituted not only by jurisprudence from the period after entry into force of the current Constitution of the Republic of Poland of 1997, but also the general principle of the democratic state of law that is read and interpreted under the former constitutional provisions after 1989 (e.g. legal certainty or requirements for the legislative process safeguarding the fundamental rights).

As presented above, fragments of the motives of the given judgments are included in the quotations. In practice this plays the role of the definitive method of interpretation. For example, on the level of argumentation, the case-law on Art. 9 of the Convention has been widely mentioned in cases: K 12/14 and K 52/13.

What is important for this study is that the case-law of the ECtHR was taken as the background for the interpretation of constitutional rights of the Polish Tribunal, which was significant, inter alia, in these discussed cases: P 12/09, K 45/14, SK 28/15, K 25/11, and SK 70/13.

Especially in SK 70/13, the Tribunal indicated a long list of case laws made by the European Court of Human Rights.

What is interesting is that in the process of applying the 'proportionality test' in case SK 65/12, the Tribunal expressly used the notion of freedom of speech presented by the European Court. Furthermore, in SK 5/12, the weighing of the interest of a parent who wished to represent the child in proceedings pending against the other parent and the interest of the child was carried out based on arguments derived from ECtHR cases. 
The Tribunal underlined expressis verbis the necessity to take into account, as part of its constitutional review, the norms and standards formulated by the European Court in order to eliminate any possible collisions between them. The standards contained in the Convention and the jurisprudence of the European Court, according to the Tribunal, may be referred to as an element of argumentation (see more in the description of case SK 3/12). In case K 37/11, the Tribunal held that the importance of the right demands the use of the standard expressed by the European Court.

It can be also observed that when controlling civil law and judging such casesboth substantive law and procedure - the national constitutional court mainly refers to the case law and the interpretation previously presented by the ECtHR.

This serves primarily to strengthen arguments on the private law content of the constitutional control template. A similar purpose is served by the reference to interpretation adopted in the judicature by CJ EU. It occurs statistically rarely, which is likely due to the fact that in the field of civil law (as well as criminal law), the competences of the European Union and the scope of EU law (and then the scope of adjudication by the EU CJEU) are limited.

In all the judgments of ECtHR presented above, direct reference to previous ECtHR decisions may be observed. As in the jurisdiction of PCT, this method is very important and frequently used.

\subsubsection{Interpretation on the basis of the case law of ordinary courts}

A few of the studied decisions refer to the jurisprudence of the national courts, but this operation is aimed not directly to the interpretation of constitutional provisions, but rather to investigate how the controlled provisions function in practice and what their practical effects are (taking not only the literal meaning but also law in action into consideration). This method is counted in this research case only if used to interpret the Constitution but not when it concerns the statutes (law-in-action) regarding what was identified. From the latter perspective, the case law of ordinary courts was not applied to 'recover' the content of constitutional standard.

\subsubsection{Interpretation on the basis of the normative acts of other domestic state organs}

The legal activities of other domestic state organs were not mentioned in the studied cases as factors influencing the decisions, in particular the national ones. In one of the cases, a document issued by an international organization (Council of Europe) was highlighted as a kind of background of the presented main argumentation.

However, the documents of public bodies or organizations were often mentioned by the parties to the procedure before the PCT (for example, statements of commissioners for fundamental rights, governments, or ministers). 
Similar conclusions may be drawn in reference to ECtHR and interpretation based on the standards and proposals of other Council of Europe bodies. Only a few of the presented decisions refer to non-binding documents of a Council of Europe system or other international body. These documents have been used by the ECtHR either as supporting (secondary) or illustrative elements. An example is case Michał Korgul v. Poland (application no. 36140/11) recalling principles of Recommendation Rec(2006)2 of the Committee of Ministers to member states on the European Prison Rules. ${ }^{156}$

\subsection{External systemic and comparative law arguments}

The method described as external systemic (comparative) interpretation, as adopted in the study, is complex (comprising a set of sub-methods). It refers to the following external systemic factors: international treaties and the case law of international courts and foreign legal systems or judicial decisions. The base for interpretation of fundamental rights is not only national law and practice but also 'uniform international content'. In particular, international treaties may naturally play a role in the interpretation of constitutional fundamental rights (and vice versa).

\subsubsection{International treaties and the case law of international courts}

The most important perspective, adopted as the general starting point of this study, is the reasoning of the Polish Constitutional Tribunal relating to the jurisprudence of ECtHR (28 cases) and CJ EU (2 cases) based on international treaties. From this perspective, the 30 abovementioned judgments were chosen because they refer to individual judgments of international tribunals, which is why every case discussed can serve as an example of this method of interpretation.

The reasoning with reference to international courts means also that the Polish Constitutional Court referred via ECtHR and CH EU judgments to the provisions of the European Convention on Human Rights and EU law that were the legal ground of the decisions taken by these international courts. Such references cover in particular the meaning and essence of fundamental rights, as well as their limitations and resolutions of the collisions (conflicts) between them in given circumstances.

The details of every case and their specifics were presented above, with the highlights grounded by the specifics of their respective branches of law (in particular civil and criminal law).

There are two decision among those selected where the PCT Constitutional Court explicitly stated that a previous ECtHR decision was one of the decisive bases for the interpretation.

156 'All detention shall be managed so as to facilitate the reintegration into free society of persons who have been deprived of their liberty.' 
The Constitutional Court referred to the judgments of CJ EU to present the content of the controlled national law based on the EU directive interpreted by CJ EU. Such existing normative content (in fact-no restriction to it was presented by the EU Court) was presented as the argument for compliance with the Polish Constitution of 1997 (which might be questionable because of the primary role of national constitutional standards in the process of control conducted by PCT).

International treaties, the case law of international courts, and other sources of international law also play a role in the examined jurisprudence of ECtHR.

In particular, the Vienna Convention on the Law of Treaties of $1969^{157}$ is mentioned in five cases. It contains several provisions on the interpretation of international treaties that should also be followed by the ECtHR. ${ }^{158}$ In only three of the decisions examined did the ECtHR present an interpretation in conjunction with other international treaties (the United Nations system).

ECtHR also recalls in the process of interpretation the meaning of international conventions presented previously by international judicial fora (UN Commission on Human Rights, European Union Court of Justice, International Court of Justice). These decisions are linked to international conventions on fundamental rights (universal or regional).

The other sources of international law were not mentioned often, even as illustrative arguments. Customary international law and so-called general principles of international law seem to be over-general and abstract concepts from the perspective of the examined private and criminal law (substantive and procedural issues).

Under Arts. 188(2) and 193 of the Constitution, the PCT shall adjudicate on the conformity of normative acts to ratified international agreements as well. In such cases, the Tribunal applies the international standard directly to the assessment of domestic law. The standard stemmed from international law is therefore not only an inspiration for the interpretation of the Constitution but also plays an independent role. This raises, e.g. the question of the extent to which the PCT may interpret the international agreements on its own, and to what extent it is bound by the interpretation shaped earlier by international tribunals, e.g. the ECtHR (case P 12/09). ${ }^{159}$

An interesting issue, generally beyond this study but worth mentioning, is the role of the European Convention (an international agreement) as a separate template (standard) of constitutional control of national statutes. The international provisions are in practice often given as an alternative (to the domestic constitution) standard.

157 See: https://bit.ly/3lGrBpN.

158 It should be noted that the application of Vienna Convention for interpretation of the European Convention was adopted in the jurisprudence of ECtHR (see: judgment of 21 January 1975, Golder v. the United Kingdom, application no. 4451/70).

159 Another is the issue of divergent interpretations of binding international law by the Polish Tribunal and by the international court. In a dissenting opinion to the judgment in case P 12/09, Judge S. Biernat made the objection that the PCT had incorrectly interpreted the ECHR's standard. This issue deserves a more in-depth analysis, but here it can be observed that this Judge mentions this issue of the application of the Convention by the Tribunal (part II, 7.H). 
It is interesting regarding the activities of the Polish Constitutional Tribunal that substantive non-compliance with the provisions of the Constitution often results in the formal discontinuation of the proceedings of examining compliance with the standard of the Convention. The statement of first non-compliance with national standards-in this solution-makes irrelevant the need to examine the latter (i.e. from the perspective of international standards). There is no such legal obligation to discontinue, but the Tribunal is guided by economy of proceedings and-as one may assume-by a reluctance to make direct statements about the compliance of the statute (domestic law) with the Convention (often similar provisions). Additionally, by doing so the PCT does not come into collision with the European courts' decisions.

It is also worth mentioning that the reasoning presented by PCT in the discussed case SK 45/09 included also a comprehensive study of the issue of the relation of national constitutional principles to the provisions and interpretation of EU law, as well as the control of the latter. ${ }^{160,161}$

\subsubsection{Interpretation according to foreign legal systems or judicial decisions}

In one case PCT presented arguments stemming from foreign legal systems or judicial decisions. In particular, foreign constitutions and decisions of similarly competent (equivalent) constitutional courts and their case law were referred to. It is noted in the Polish literature on constitutional law that the jurisprudence of the domestic tribunal is influenced by concepts presented by the German constitutional court, ${ }^{162}$ and sometimes also by the French Constitutional Council and the American Supreme Court. Interpretations presented by the German constitutional court have had the greatest influence on Polish constitutional doctrine and jurisprudence. In one of the examined cases, there was a reference by PTC to the Bundesverfassungsgericht (case SK 45/09, points 2.8 and 8.2 of the reasons).

Such examples cannot be found in the abovementioned argumentation presented in this research in the corresponding cases before ECtHR and CJ EU.

\subsubsection{Other sources of international character in the interpretation of the constitution}

The reasoning in one studied case took directly into account a document of international genesis but not of binding character. This example is case SK 27/16, where PCT noted that the examined constitutional problem (institution of 'frozen funds')

160 In this judgment the Constitutional Tribunal called itself 'the court of the last word'. See Półtorak, Dudzik, 2012, pp. 225-258. The authors underline that: 'this self-determination characterizes well the whole hitherto delivered line of jurisprudence of the Tribunal in European matters. In spite of the persevering doubts as to the scope of its jurisdiction at the juncture between EU and Polish law'. See also: Kowalik-Bańczyk, 2005, p. 1355; Łazowski, 2007, pp. 148-162; Kabat-Rudnicka, 2014, pp. 95-106; Kustra, 2017, pp. 36-50; Kwiecień, 2019.

161 See also the comprehensive e-publication edited by Bureau of Tribunal, 2014;.

162 See also: Bainczyk, 2017. 
can be treated as an element of the implementation of Principle 6 of Recommendation Rec(2006)2 of the Committee of Ministers to member states on the European Prison Rules ${ }^{163}$ (facilitating persons deprived of liberty in reintegrating into society; details presented above).

\subsection{Teleological interpretation}

It is assumed that a teleological interpretation means that the constitutional court (when applying constitutional law) identifies the meaning of legal regulations with reference to their objective goals and social purpose, which can be found, e.g. in the preamble or the social function implied by the provisions that the legislator intended to fulfill. It is not often used but is substantially important argumentation, including the main reasons for the codification, existence, and function or goals of the given legislative instrument.

This method was identified in four PTC cases. In case K 12/14, the Tribunal presented teleological argumentation when examining the freedom of conscience in regard to physicians, ${ }^{164}$ and in deciding case K 52/13, this method was applied to recover the content of freedom of religion and its possible proportional restrictions. The references to the preamble were presented.

\subsection{Historical interpretation}

Applying historical interpretation means for the purpose of this part of study that the initial will and purpose of legislator (a kind of inner intention of the persons involved in law-making process of the given legal norm) is taken into consideration, such as drafts, explanatory reports, ministerial justifications, and parliamentary debates. It is worth emphasizing that the law-making process in recent decades in Poland can be easily reconstructed years later if desired for the purpose of discovering the real will of the legislator. The websites of both the lower house (Sejm) and the upper house (Senate) of Parliament provide access to electronic versions of documents from previous terms. ${ }^{165}$

Historical interpretation was used by PCT four times in the abovementioned cases. It was grounded by the role of both previous decisions of PCT and the details of the legislative process, including the explanatory reports on the amendments. An

163 See: https://bit.ly/3ApVYXz.

164 When reasoning the Tribunal presented a variety of methods-interpretation in the light of general principle (e.g. salus aegregoti suprema lex esto), axiological, historical interpretation, and argumentation based on precedents of the European courts.

165 Among them are bills (including later amended versions) with justifications, well-established debates in legislative and plenary committees, and legal opinions of central state institutions, the judiciary, and experts.

See: https://www.sejm.gov.pl/Sejm9.nsf/page.xsp/archiwum and https://www.senat.gov.pl/ poprzednie-kadencje/. 
interesting example is case P 12/09 and the relevance to PCT of previous precedents including such a method (noting that a sense of dignity and authority are among the prerequisites for effective performance of constitutional duties assigned to the Head of State).

Historical interpretation is not widely used by the ECtHR in the examined cases. It is mentioned in the abovementioned provisions of the Vienna Convention as the important method of interpretation of international treaties, i.e., the domain of ECtHR and CJ EU. In particular, travaux préparatoires and explanatory reports should play an important role in the interpretation of the European Convention.

The explanation why historical arguments were not widely used by the ECtHR in the examined cases may be the abovementioned observation that ECtHR widely references previous cases and judgments. The detailed arguments of travaux préparatoires and explanatory reports were likely presented in these older rulings in detail and there was no need to refer to all of them in the examined judgments, issued in the last decade.

\subsection{Arguments based on scholarly works}

Legal literature (articles, commentaries, monographs) plays a significant role in the interpretation and reasoning of PCT, not only in a kind of confirmatory role, but in 10 decisions as common opinions taken into consideration when shaping the limits of given fundamental rights versus other constitutional principles. In eight of the discussed cases, PTC referred to the legal literature, of which it gave its precise views and, if necessary, advocated one of the doctrinal positions.

What might be surprising from the domestic point of view (but not from the perspective of international tribunals) is that the legal literature was neither quoted not referred to (in support of the ruling) in the examined ECtHR and CJ EU decisions.

\subsection{Interpretation in light of general legal principles}

The role of principles of law (written ones explicated in legal texts) in the interpretation of fundamental rights was presented in detail above (see Section 3.1). This section refers to the general principles and values determining the provisions of the Constitution that are implicit in though not directly expressed in the Constitution. It should be noted that some general principles of law are in fact codified or may be interpretated from statutory provisions (in particular from general provisions of a given act) in which different words are used.

It may be argued that four of the decisions contain a reference to general legal principles: ignorantia juris neminem excusat and in dubio pro libertate (close to 'everything that is not forbidden is allowed'), as well as to the doctrine of effectiveness.

It may be added that in some cases the PTC did not use this 'more professional' method of interpretation, probably not due to its non-importance, but rather because of the assumption in a given case that written constitutional principles apply and 
that clara non sunt interpretanda, as well as when in fact there is no alternative to the everyday meaning of the words making up the legal provisions.

The important legal values protected by the Council of Europe, in particular the ECHR, is combined with the doctrine of effectiveness. Since 1975 it has been applied in cases-also in all of the examined ones-regarding access to a court under Art. 6(1) of European Convention. ${ }^{166}$

ECtHR takes into account a number of legal principles when interpreting the European Convention. Some of them, as mentioned above, are principles of international law expressly non-codified in the Vienna Convention (but directly interpreted from it).

\subsection{Non-legal arguments}

Arguments that could be assessed as non-legal have not been explicitly indicated by PTC as motives that would affect one and not another understanding of, for example, constitutional principles. It seems that this is related to a very broad (in constitutional judiciary) perception of general principles,, which are co-formulated by a number of factors, as well as the legal effect of actual circumstances.

\section{The relationship between the arguments}

As the Constitution is a special normative text that differs from 'ordinary' sources of law (related to its political significance, its content and function, its place in the hierarchy of sources of law, its language and context, the way it was created, its enforcement, and many other features), the constitutional interpretation (of constitutional fundamental rights by the Constitutional Courts or the ECtHR/ECJ) may thus differ from the 'traditional' interpretation of statutory law. Although there are overlaps between the two, the constitutional reasoning presented by the constitutional court and the application of the constitutional content as standards (templates) is based partly on sources and methods other than the interpretation of the ordinary provisions of law by courts dealing typically with civil and criminal cases. ${ }^{167}$

As far as the relationship between the arguments and style of the decisions is concerned, we emphasize the tests used by the constitutional court in its judging. They are connected with the 'collisional' principle stated in Art. 31 of the Polish Constitution of 1997, stating that a constitutional (fundamental) right may be restricted only in order to allow the exercise of another fundamental rights, but respecting

166 See: Guide on Art. 6 of the European Convention on Human Rights Right to a fair trial (civil limb), updated to 31 December 2020. See: https://bit.ly/2VTFJ6b.

167 See more: Tóth, 2016. 
(without prejudice to) the essential content, and proportionately to the objective and to the extent that is necessary. The test is often applied in former (older than last 10 years) constitutional case law.

Both the Polish Constitutional Tribunal and the European Court of Human Rights often present in their reasoning the method of 'weighing' fundamental principles and rights, in particular from the perspective of proportionality and the 'collisions' of given principles and standards with others, also of fundamental character.

The methods and effects of interpretation presented by the European Court are mainly directly often taken into account by the domestic Tribunal when considering cases. It sometimes happens, although on a smaller scale (because it deals with such cases less often due to its limited competences), that the rulings of the CJ EU play a similar role. They are very often used in arguments presented by the parties, and are also often used by the Constitutional Tribunal when adjudicating. This observation refers both to the arguments of the parties in the proceedings for compliance or noncompliance and the arguments of the Tribunal in favor of an alternative decision.

The very course of reasoning during adjudication (in both cases: conformity tests) is similar in the proceedings before the Constitutional Tribunal and the European Court. First, the content of the standard of control is explained (from the Constitution or the European Convention), and then the 'reference' to this content (template), in turn, of the content of the provision under review. This jurisprudential practice is important for both courts to determine this content.

The method used by PTC and the ECtHR is also an application of the 'living instrument" doctrine (an evolutive or dynamic interpretation). Since the famous decision of 1978 (Tyrer v. the United Kingdom, application No. 5856/72), ${ }^{168}$ it has been widely applied in interpreting the European Convention.

\section{Style of PCT decisions}

The PCT's style of reasoning is partly 'enunciative', where the court presents quasi-ex cathedra statements (without a detailed consideration and comparison of arguments and counter-arguments), and partly 'discursive-arguing', where the ruling decision is based on balancing arguments and counter-argument, after analyzing and accepting or rejecting the arguments of petitioners (giving a legal answer).

In all the discussed examples, the subject of the interpretation was the normative content of the national constitution (including fundamental rights) as control templates (models, standards). The content of the latter have often been influenced by the interpretation of the European Convention delivered in rulings of the European Court that the national constitutional tribunal referred to on the merits. 
A qualitative-analytical analysis allowed us to draw the abovementioned conclusions on the methods of interpretation used by the European Court or the CJ EU in their decisions, the style of reasoning and decision-making that characterizes these regional decision-making fora, and the characteristics of the decision-making of the European Court or the CJ EU that may be of interest to the scientific community.

Key concepts presented in reasoning are fundamental rights, principles determining the functioning of the legal system, and dogmatic categories. The most important are: proportionality, the legal democratic state, and legal certainty. These aspects have a preponderant influence on the tribunal's conception of law and interpretation. Several important fundamental rights and international standards have been identified above in the course of constitutional adjudication, in particular to resolve substantive contradictions between competing fundamental rights of the same hierarchy. They are very close, in most cases even quite similar, to the tests and standards applied by the ECtHR in the corresponding judgments.

A comparable, even similar, key stage in the constitutional review is the determination of the content of the control template (i.e., the standard interpretation of the Constitution), which results from the general provisions of the Constitution and jurisprudence to date. At this stage, the jurisprudence of the European Court, including the considerations contained in the justifications, also de facto shapes the content of the control template, or at least indirectly affects the interpretation of these templates for control (establishing their substantive content). Sometimes this happens indirectly when the Tribunal refers directly to its last line of jurisprudence, which had been formed with reference to case law and reasoning resulting from the decisions of the European Court. It should be added that some provisions of the Constitution are similar in substance (and even wording) to the provisions of the ECtHR. The abovementioned phenomenon is then more intense, and the possibilities of using the case law of the European Court are greater.

It can be also observed that the predominant direct or indirect use (recalling of justification) of theses and reasoning drawn from the judgments of the European Court leads in some cases to a kind of reinforcement of arguments. In effect, a kind of domestic reasoning in favor of an internationally harmonized interpretation of constitutional control templates may be observed.

The direct 'addressees' of the decisions and the statement of reasons presented by PTC are either petitioners: judges (courts) or lawmakers (bodies involved in the legislative process), depending on the type (procedure) of constitutional control and the way of initiating it (e.g. during the proceedings explained above or in an issue re-opened from one side, or as a part of the parliamentary legislative process with the impact of President from another side). The indirect 'addressees' are lawyers and in fact all citizens, because the judgments may generally influence their rights and obligations in similar cases. NGOs and international extrajudicial bodies may also be interested in taking into consideration the effects of the adopted interpretation, especially in their comments, statements in other proceedings before tribunals, or in future activities, including public comments. 


\section{Final conclusions}

Summarizing this chapter, the main results of this examination of the jurisprudence of the Polish Constitutional Tribunal and the ECtHR or CJ EU may be presented, mainly regarding their methods of interpretation, including the style of reasoning and the key concepts applied. The detailed considerations presented above may be grounded in the following, mainly qualitative, general conclusions concerning the topic of this legal study from the Polish perspective.

The above detailed study presented, first of all, important judgments of the national constitutional court from recent years, which included an interpretation showing an unique interaction with the interpretation (and hence with argumentation methods) previously adopted by European international courts (ECtHR, CJ EU). Previously somewhat invisible work was done on such a review of national case law from the last 10 years and on the selection of national decisions to be accurately presented so that all of them contain references to international standards. Hence, as the figures were based solely on these selected cases, the statistical conclusion would not be valid that in all its domestic decisions, the Polish Constitutional Tribunal uses the methods of interpretation and their effects adopted by international tribunals when determining the content of control standards resulting from the legal system of the Council of Europe or European Union law.

On the other hand, the conclusion that such situations and interactions have occurred in some of the settled cases is certainly correct methodologically. To this should be added the observation that the parties' pleadings and the arguments presented therein often refer to the jurisprudence of European courts. It can even be said that in the last 10 years under study, such a mode of drawing up applications and letters addressed to PCT has greatly developed, sometimes even in exaggerated form due to a lack of international standards relating to the detailed circumstances of the case or the wide margin of freedom of national law resulting from the ECtHR (which the Court itself notes). This study shows that the interaction between the jurisdiction of the given national tribunal and the adjudication by European tribunals has also occurred within the scope of creating the content of fundamental standards of a legal order resulting from normative acts that are applied by a given institution.

Generally speaking, the reasoning style and decision template of a given national constitutional court in principle does not differ greatly from the reasoning style or decision template of the European Court in similar cases. The way the Polish Constitutional Tribunal assesses the constitutionality of domestic norms shows strong similarities with the manner in which the European Court assesses the conventionality of the domestic decisions of the States' courts. The main similarity is the process of 'weighing the values' (arising from constitutional or European Convention standards) and laying stress on the argumentation method of interpretation. The Polish Tribunal widely uses the case-law and way of reasoning of the European Court in similar cases. 
As far as the details of interpretation are concerned, the main methods of interpretation used by the Tribunal and European Court in the analyzed cases were:

- contextual,

- grammatical (textual),

- logical (linguistic-logical), and

- teleological.

What was important, however, was the significant place occupied in all types of interpretation by the currently existing jurisprudential background. The case-law has usually taken the key place in the argumentation of the court. In the jurisprudence of the domestic constitutional court, arguments presented as legal doctrine are much more often used, and books and legal studies of the periodical literature are quoted.

I would argue that the statistical frequency of the argument types in the discussed group of cases (pre-chosen for relevant references between domestic tribunals and both European tribunals) may not match their practical role in the general jurisprudence of the PTC, but they do provide a qualitive and substantive perspective on its jurisprudence 'in action'. The types of arguments that play a decisive role in decision-making or reasoning cannot be assessed on a quantitative basis, but rather qualitatively: The decisive arguments leading to a particular conclusion were mainly based on previous PCC rulings and arguments that had been presented by this occasion. Also, the rulings of ECtHR in 'Polish individual cases' and CJ EU judgments played a decisive role. An approach that could be described as close to a res iudicata doctrine may be observed in such cases. Defining arguments that played a significant role in the reasoning of PCC and ECtHR or CJ EU, not alone but with another arguments, were identified in some cases. Their sum total justified the decision taken, or they played an accessory role to the decisive arguments. Strengthening arguments that in fact shape the decision taken are of great importance in the jurisprudence of PCT. They strengthen the legitimacy of the decision in many cases and often play a role similar to that of the defining arguments. Finally, illustrative arguments that theoretically do not directly affect the decision-making could be also observed. Examples include the bracketed comments and comparative remarks (e.g. on the ground of German constitutional law) presented additionally by the court to show that it was aware of them, but which did not play a role in reaching the conclusion. 


\section{Bibliography}

BAINCZYK, M. (2017) 'Polski i niemiecki Trybunał Konstytucyjny wobec członkostwa państwa w Unii Europejskiej', Wroclaw: E-Wydawnictwo. Prawnicza i Ekonomiczna Biblioteka Cyfrowa [E-Publisher. Legal and Economic Digital Library].

BocHEŃSKI, M. (2016) 'Practical aspects of assessment of risk of re-offending by "especially dangerous" offenders in the context of the judgment of the Constitutional Tribunal of 23 November 2016 (K 6/14)', Problems of the Forensic Sciences, Vol. 108, pp. 632-650.

BosEK, L. (2015) 'The essence of the constitutional freedom of the person,' Polish Law Review, Vol. 1, pp. 17-31.

BRzozowski, W. (2017) 'Prawo lekarza do sprzeciwu sumienia', Państwo i Prawo, Vol. 7, pp. 23-36.

Bureau of Tribunal (2014) Selected rulings of the Polish Constitutional Tribunal: The law of the European Union in jurisprudence of Polish Constitutional Tribunal (2003-2014). Warsaw: https://bit.ly/3i8KmBd (Accessed: 1 June 2021).

ChMielarz-Grochal A., SuŁKowsKi J. (2018) 'Appointment of judges to the Constitutional Tribunal in 2015 as the trigger point for a deep constitutional crisis in Poland', Przeglad Konstytucyjny, Vol. 2, pp. 91-119 https://bit.ly/3i7RQ7E (Accessed: 31 May 2021).

European Commission for Democracy through Law (Venice Commission), Poland. Opinion 860/2016 on the Act on the Constitutional Tribunal Adopted at its 108th Plenary Session (14-15 October 2016), CDL-AD(2016)026; https://bit.ly/3kCFh5Y (Accessed: 31 May 2021).

GARLICKI, L. (2007) 'Constitutional courts versus supreme courts', I CON, 5(1), pp. 44-68.

GĘSICKA, D.K. (2015) 'The Judgment of the Polish Constitutional Tribunal of 23 June 2015 (no. SK 32/14)Case Note (Partially Approving)', Comparative Law Review, Vol. 19, pp. 205-218.

GóRSKI A., KLONOWSKI M. (2018), 'Dozwolone granice krytyki władzy sądowniczej w świetle orzecznictwa Europejskiego Trybunału Praw Człowieka (Permitted limits of criticism of the judiciary in the light of case law of the European Court of Human Rights)', Europejski Przegląd Sądowy, Vol. 1, pp. 24-28.

Guide on Art. 6 of the European Convention on Human Rights Right to a fair trial (civil limb), updated to 31 December 2020, https://bit.ly/3CMJJ8A (Accessed: 1 May 2021).

KABAT-RUDNiCKA, D. (2014) 'European integration in the light of the Polish Constitutional Court's judgments', in Konopacki, S. (ed.) (2014), Europe in the Time of Crisis. Wydawnictwo Uniwersytetu Łódzkiego [Lodz University Publisher] https://www.ceeol.com/search/ chapter-detail?id=797441 (Accessed: 17 May 2021).

KLUZA, J. (2018) 'On the limits of the Ne Bis In Idem and Lex Retro Non Agit principles: Remarks in view of the judgment of the Constitutional Tribunal regarding the so-called "Act on Beasts"', Krytyka Prawa, Vol. 3, pp. 59-74.

KOWALIK-BAŃCZYK, K. (2005) 'Should we Polish it up? The Polish Constitutional Tribunal and the idea of supremacy of EU law', German Law Journal, 6(10), pp. 1355-1366.

KustrA, A. (2016) 'Poland's constitutional crisis: From court-packing agenda to denial of Constitutional Court's judgments', Toruńskie Studia Polsko-Włoskie-Studi Polacco Italiani di Toruń, 12, pp. 343-366. https://bit.ly/3F2dl3I (Accessed: 15 June 2021).

Kustra A. (2017) 'The judgment of Polish Constitutional Court in case Supronowicz (SK 45/09): The constitutional borrowing of "Solange" formula and its outcomes for the European judicial dialogue', European Journal of Public Matters, Vol. 1, pp. 36-50. 
KWIECIEŃ, R. (2019) 'The Court of Justice, the National Courts, and the controversy over the "ultimate arbiter" of the constitutionality of law in the European Union', Polish Review of International and European Law, 8(1), pp. 9-41. https://bit.ly/31Z8t6D (Accessed: 15 June 2021).

ŁAZOWSKI, A. (2007) 'Accession treaty-Polish Constitutional Tribunal conformity of the Accession Treaty with the Polish Constitution: Decision of 11 May 2005, European Constitutional Law Review, 3(1), pp. 148-162.

ŁĘTOWSKA, E., GrochowsKi, M., WiEWiÓROWSKA-DOMAGALSKA, A. (2015) 'Binding, but not convincing (on the Constitutional Tribunal judgment in case K 52/13 on ritual slaughter) [Wiąże, ale nie przekonuje (wyrok Trybunału Konstytucyjnego w sprawie K 52/13 o uboju rytualnym)]', Państwo i Prawo, 6, pp. 53-66.

MÜSIG, U. (2015) 'Reconsidering constitutional formation: The Polish May Constitution 1791 as a masterpiece of constitutional communication', Czasopismo Prawno-Historyczne, Vol. 1, pp. 75-93.

OLSzóWKA, M. (2019) 'Analiza projektu ustawy o zmianie ustawy o zawodach lekarza i lekarza dentysty, ustawy o diagnostyce laboratoryjnej oraz ustawy o zawodach pielęgniarki i położnej, zawartego w druku senackim nr 1034/ix kadencja (sprzeciw sumienia)', Studia z Prawa Wyznaniowego, 22, pp. 376-377.

PoDKowiK J. (2017) 'Bezpośrednie konstytucyjne granice wolności człowieka', Państwo $i$ Prawo, Vol. 8, pp. 42-61.

Podkowik, J., Zubik, M. (2021) 'Data retention in Poland', in Zubik, M., Podkowik, J., Rybski, R. (eds.) (2021) European Constitutional Courts toward Data Retention Laws. Cham: Springer.

Polish Constitution of 1791-materials, Polish History Museum in Warsaw and at: https://bit. ly/2Wdw9LN (Accessed: 20 May 2021).

Polish Constitution of 1791, translation into English by F. Bukaty with foreword by A. Grześkowiak-Krwawicz, https://bit.ly/3EQndgI (Accessed: 20 May 2021).

PóŁTORAK, N., DuDZIK, S. (2012) “"The Court of the Last Word”: Competences of the Polish Constitutional Tribunal in the review of European Union law', Yearbook of Polish European Studies, 15, pp. 225-258; https://www.ceeol.com/search/article-detail?id=197788 (Accessed: 17 May 2021).

RAdzIEWicz, P. (2017) 'Refusal of the Polish Constitutional Tribunal to apply the act stipulating the constitutional review procedure', Review of Comparative Law, 28(1), pp. 23-40.

SAKOwICZ, A. (2019) 'Zakaz dowodowego wykorzystania wyjaśnień podejrzanego występującego bez obrońcy bądź pod nieobecność obrońcy (Prohibition of using the suspect's statements as evidence if the suspect appears without a defense lawyer or when the defense lawyer is absent)', Europejski Przegląd Sądowy, Vol. 1, pp. 47-54.

STEINBORN, S. (2019) 'Access to a defense lawyer at an early stage of criminal procedure: De lege lata and de lege ferenda remarks (Dostęp do obrońcy na wczesnym etapie postępowania karnego. Uwagi de lege lata i de lege ferenda)', Europejski Przegląd Sądowy, Vol. 1, pp. 38-46.

Szmulik, B., SzymaneK, J. (2020) Legal Dispute over the Constitutional Court in Poland. Warsaw: Wydawnictwo Instytutu Wymiaru Sprawiedliwości [The Institute of Justice Press].

Team of Experts, Report of 15 July 2016 on the Issues Related to the Constitutional Tribunal, https://bit.ly/3i7WAKy (Accessed: 20 May 2021). 
Tотн, Z. (2016) 'The Methods of Statutory Interpretation in the Practice of the High Courts of Hungary', Annales Universitatis Mariae Curie-Sklodowska Lublin-Polonia, 1(M), pp. 173-201.

Tuleja, P., RAdZIEWICZ, P. (eds.) (2017) Konstytucyjny spór o granice zmian organizacji $i$ zasad działania Trybunału Konstytucyjnego czerwiec 2015-marzec 2016. Warsaw: Wolters Kluwer Poland.

WiŚNIEWSKI, A. (2020) 'The impact of the European Convention of Human Rights on the Polish legal system', Polish Review of International and European Law, 9(1), pp. 153-183.

WóJCIKIEWICZ, J., KWIATKOWSKA-WóJCIKIEWICZ, V. (2017) 'The constitutionality of taking DNA reference samples', Comparative Law Review, Vol. 23, pp. 207-222; https://doi. org/10.12775/CLR.2017.009. 


\section{List of selected decisions}

\begin{tabular}{|c|c|c|}
\hline 1. & $\begin{array}{l}\text { Judgement of Constitutional Tri- } \\
\text { bunal of } 6.6 .2011 \text { (Ref. No. P 12/09) }\end{array}$ & $\begin{array}{l}\text { Judgement of the European Court of Human } \\
\text { Rights of 21.1.1999, Janowski v. Poland (ap- } \\
\text { plication no. 25716/94) }\end{array}$ \\
\hline 2. & $\begin{array}{l}\text { Judgement of Constitutional Tri- } \\
\text { bunal of } 11.10 .2011 \text { (Ref. No. K } \\
\text { 16/10) }\end{array}$ & $\begin{array}{l}\text { Judgement of the European Court of Human } \\
\text { Rights of } 26.3 .1985, \mathrm{X} \text { and Y v. Netherlands; } \\
\text { (application no. 8978/80) }\end{array}$ \\
\hline 3. & $\begin{array}{l}\text { Judgement of Constitutional } \\
\text { Tribunal of } 16.11 .2011 \text { (Ref. No. } \\
\text { SK 45/09) }\end{array}$ & $\begin{array}{l}\text { Judgement of the European Court of Human } \\
\text { Rights of } 30.6 .2005 \text {, Bosphorus Hava Yollari } \\
\text { Turizm ve Ticaret Anonim Şirketi v. Ireland } \\
\text { (application no. 45036/98) }\end{array}$ \\
\hline 4. & $\begin{array}{l}\text { Judgement of Constitutional Tri- } \\
\text { bunal of } 23.10 .2012 \text { (Ref. No. SK } \\
11 / 12 \text { ) }\end{array}$ & $\begin{array}{l}\text { Judgement of the European Court of Human } \\
\text { Rights of of } 22.6 .2004 \text {, Broniowski v. Poland } \\
\text { (application no. 31443/96) }\end{array}$ \\
\hline 5. & $\begin{array}{l}\text { Judgement of Constitutional Tri- } \\
\text { bunal of 20.11.2012 (Ref. No. SK } \\
\text { 3/12) }\end{array}$ & $\begin{array}{l}\text { Judgement of the European Court of Human } \\
\text { Rights of 19.5.2009, Kulikowski v. Poland (ap- } \\
\text { plication no. 18353/03) }\end{array}$ \\
\hline 6. & $\begin{array}{l}\text { Judgement of Constitutional Tri- } \\
\text { bunal of } 10.12 .2012 \text { (Ref. No. K } \\
25 / 11 \text { ) }\end{array}$ & $\begin{array}{l}\text { Judgement of the European Court of Human } \\
\text { Rights of 25.3.1983, Silver and Others v. The } \\
\text { United Kingdom (application no. 5947/72; } \\
\text { 6205/73; 7052/75; 7061/75; 7107/75; } \\
\text { 7113/75; 7136/75) }\end{array}$ \\
\hline 7. & $\begin{array}{l}\text { Judgement of Constitutional Tri- } \\
\text { bunal of } 11.12 .2012 \text { (Ref. No. K } \\
\text { 37/11) }\end{array}$ & $\begin{array}{l}\text { Judgement of the European Court of Human } \\
\text { Rights of Rybacki v. Poland (application no. } \\
52479 / 99 \text { ) }\end{array}$ \\
\hline 8. & $\begin{array}{l}\text { Judgement of Constitutional } \\
\text { Tribunal of 14.1.2014 (Ref. No. SK } \\
\text { 25/11) }\end{array}$ & $\begin{array}{l}\text { Judgement of the European Court of Human } \\
\text { Rights of of 9.10.1979, Airey v. Ireland (appli- } \\
\text { cation no. 6289/73) }\end{array}$ \\
\hline 9. & $\begin{array}{l}\text { Judgement of Constitutional Tri- } \\
\text { bunal of 21.1.2014 (Ref. No. SK } \\
5 / 12 \text { ) }\end{array}$ & $\begin{array}{l}\text { Judgement of the European Court of Human } \\
\text { Rights of 19.6.2007, W.S. v. Poland (application } \\
\text { no. 21508/02) }\end{array}$ \\
\hline 10. & $\begin{array}{l}\text { Judgement of Constitutional Tri- } \\
\text { bunal of 25.2.2014 (Ref. No. SK } \\
65 / 12 \text { ) }\end{array}$ & $\begin{array}{l}\text { Judgement of the European Court of Human } \\
\text { Rights of 7.12.1976, Handyside v. The United } \\
\text { Kingdom (application no. 5493/72) }\end{array}$ \\
\hline
\end{tabular}




\begin{tabular}{|c|c|c|}
\hline 11. & $\begin{array}{l}\text { Judgement of Constitutional Tri- } \\
\text { bunal of 15.4.2014 (Ref. No. SK } \\
\text { 12/13) }\end{array}$ & $\begin{array}{l}\text { Judgement of the European Court of Human } \\
\text { Rights of } 28.10 .1998 \text {, Aït-Mouhoub v. France } \\
\text { (application no. 22924/93) }\end{array}$ \\
\hline 12. & $\begin{array}{l}\text { Judgement of Constitutional } \\
\text { Tribunal of 30.6.2014 (Ref. No. K } \\
\text { 23/11) }\end{array}$ & $\begin{array}{l}\text { Judgement of Court of Justice of the European } \\
\text { Union of 8.4.2014, Digital Rights Ireland Ltd v. } \\
\text { Minister for Communications, Marine and } \\
\text { Natural Resources, Ireland; Kärntner Landesr- } \\
\text { egierung v. M. Seitlinger and others (C-293/12, } \\
\text { C-594/12) }\end{array}$ \\
\hline 13. & $\begin{array}{l}\text { Judgement of Constitutional Tri- } \\
\text { bunal of 25.11.2014 (Ref. No. K } \\
54 / 13 \text { ) }\end{array}$ & $\begin{array}{l}\text { Judgement of the European Court of Human } \\
\text { Rights of } 16.10 .2001 \text {, Brennan v. United } \\
\text { Kingdom (application no. } 39846 / 98\end{array}$ \\
\hline 14. & $\begin{array}{l}\text { Judgement of Constitutional Tri- } \\
\text { bunal of Tribunal of } 10.12 .2014 \\
\text { (Ref. No. K 52/13) }\end{array}$ & $\begin{array}{l}\text { Judgement of the European Court of Human } \\
\text { Rights of 27.6.2000, Cha'are Shalom Ve Tsedek } \\
\text { v. France (application no. 27417/95) }\end{array}$ \\
\hline 15. & $\begin{array}{l}\text { Judgement of Constitutional Tri- } \\
\text { bunal of 12.2.2015 (Ref. No. SK } \\
\text { 70/13) }\end{array}$ & $\begin{array}{l}\text { Judgement of the European Court of Human } \\
\text { Rights of 27.10.2003, Skałka v. Poland (appli- } \\
\text { cation no. 43425/98) }\end{array}$ \\
\hline 16. & $\begin{array}{l}\text { Judgement of Constitutional Tri- } \\
\text { bunal of 23.6.2015 (Ref. No. SK } \\
\text { 32/14) }\end{array}$ & $\begin{array}{l}\text { Judgement of Court of Justice of the European } \\
\text { Union of 10.4.2014, ACI Adam BV and others } \\
\text { v. Stichting Onderhandelingen Thuiskopie ver- } \\
\text { goeding (C-435/12) }\end{array}$ \\
\hline 17. & $\begin{array}{l}\text { Judgement of Constitutional Tri- } \\
\text { bunal of 22.9.2015 (Ref. No. SK } \\
21 / 14 \text { ) }\end{array}$ & $\begin{array}{l}\text { Judgement of the European Court of Human } \\
\text { Rights of 20.12.2007, Paykar Yev Hagh- } \\
\text { tanak Ltd v. Armenia (application } \\
\text { no. 21638/03) }\end{array}$ \\
\hline 18. & $\begin{array}{l}\text { Judgement of Constitutional } \\
\text { Tribunal of } 7.10 .2015 \text { (Ref. No. K } \\
\text { 12/14) }\end{array}$ & $\begin{array}{l}\text { Judgement of the European Court of Human } \\
\text { Rights of 7.7.2011, Bayatyan v. Armenia (ap- } \\
\text { plication no. 23459/03) }\end{array}$ \\
\hline 19. & $\begin{array}{l}\text { Judgement of Constitutional } \\
\text { Tribunal of 17.5.2016 (Ref. No. } \\
\text { SK 37/14) }\end{array}$ & $\begin{array}{l}\text { Judgement of the European Court of Human } \\
\text { Rights of 26.7.2005, Podbielski and PPU } \\
\text { Polpure v. Poland (application no. 39199/98) }\end{array}$ \\
\hline 20 & $\begin{array}{l}\text { Judgement of Constitutional Tri- } \\
\text { bunal of } 11.10 .2016 \text { (Ref. No. SK } \\
28 / 15 \text { ) }\end{array}$ & $\begin{array}{l}\text { Judgement of the European Court of Human } \\
\text { Rights of 7.12.2006, van der Valen v. Nether- } \\
\text { lands (application no. 29514/05) }\end{array}$ \\
\hline 21. & $\begin{array}{l}\text { Judgement of Constitutional } \\
\text { Tribunal of } 8.11 .2016 \text { (Ref. No. P } \\
\text { 126/15) }\end{array}$ & $\begin{array}{l}\text { Judgement of the European Court of Human } \\
\text { Rights of } 29.10 .1991 \text {, Helmers v. Sweden (ap- } \\
\text { plication no. } 11826 / 85 \text { ) }\end{array}$ \\
\hline
\end{tabular}




\begin{tabular}{|c|c|c|}
\hline 22 & $\begin{array}{l}\text { Judgement of Constitutional Tri- } \\
\text { bunal of 23.11.2016 (Ref. No. K } \\
6 / 14 \text { ) }\end{array}$ & $\begin{array}{l}\text { Judgement of the European Court of Human } \\
\text { Rights of 10.5.2010, M. v. Germany (application } \\
\text { no. 19359/04) }\end{array}$ \\
\hline 23. & $\begin{array}{l}\text { Judgement of Constitutional } \\
\text { Tribunal of } 1.12 .2016 \text { (Ref. No. K } \\
\text { 45/14) }\end{array}$ & $\begin{array}{l}\text { Judgement of the European Court of Human } \\
\text { Rights of } 10.2 .2009 \text {, Zolotukhin v. Russia (ap- } \\
\text { plication no. } 14939 / 03 \text { ) }\end{array}$ \\
\hline 24. & $\begin{array}{l}\text { Judgement of Constitutional Tri- } \\
\text { bunal of 4.4.2017 (Ref. No. P 56/14) }\end{array}$ & $\begin{array}{l}\text { Judgement of the European Court of Human } \\
\text { Rights of 27.4.2000, Tiemann versus France } \\
\text { and Germany (application no. } 47457 / 99, \\
47458 / 99 \text { ) }\end{array}$ \\
\hline 25. & $\begin{array}{l}\text { Judgement of Constitutional Tri- } \\
\text { bunal of 21.6.2017 (Ref. No. SK } \\
\text { 35/15) }\end{array}$ & $\begin{array}{l}\text { Judgement of the European Court's judgement } \\
\text { of 24.5.2006, Weissman and Others v. Romania } \\
\text { (application no. 63945/00) }\end{array}$ \\
\hline 26. & $\begin{array}{l}\text { Judgement of Constitutional Tri- } \\
\text { bunal of 7.3.2018 (Ref. No. K 2/17) }\end{array}$ & $\begin{array}{l}\text { Judgement of the European Court of Human } \\
\text { Rights of 5.1.2000, Beyeler v. Italy (application } \\
\text { no. 33202/96) }\end{array}$ \\
\hline 27. & $\begin{array}{l}\text { Judgement of Constitutional Tri- } \\
\text { bunal of 24.4.2018 (Ref. No. SK } \\
\text { 27/16) }\end{array}$ & $\begin{array}{l}\text { Judgement of the European Court of Human } \\
\text { Rights of of 21.3.2017, Michał Korgul v. Poland } \\
\text { (application no. 36140/11 }\end{array}$ \\
\hline 28. & $\begin{array}{l}\text { Judgement of Constitutional } \\
\text { Tribunal of 11.7.2018 (Ref. No. } \\
\text { SK 3/17) }\end{array}$ & $\begin{array}{l}\text { Judgement of the European Court of Human } \\
\text { Rights of 23.10.1996, Levages Prestations Ser- } \\
\text { vices v. France (application no. 21920/93) }\end{array}$ \\
\hline 29. & $\begin{array}{l}\text { Judgement of Constitutional } \\
\text { Tribunal of 5.11.2019 (Ref. No. P } \\
\text { 14/19) }\end{array}$ & $\begin{array}{l}\text { Judgement of the Court of Justice of European } \\
\text { Union of 25.1.2017, Stowarzyszenie "Oławska } \\
\text { Telewizja Kablowa" w Oławie v. Stowar- } \\
\text { zyszenie Filmowców Polskich w Warszawie } \\
\text { (C-367/15) }\end{array}$ \\
\hline 30. & $\begin{array}{l}\text { Judgement of Constitutional Tri- } \\
\text { bunal of } 2.12 .2020 \text { (Ref. No. SK } \\
\text { 9/17) }\end{array}$ & $\begin{array}{l}\text { Judgement of the European Court of Human } \\
\text { Rights of } 10.1 .2006 \text {, Teltronic-CATV v. Poland } \\
\text { (application no. 48140/99) }\end{array}$ \\
\hline
\end{tabular}


PIOTR MOSTOWIK

\begin{tabular}{|c|c|c|c|c|c|}
\hline \multicolumn{3}{|c|}{ Methods } & \multicolumn{2}{|c|}{ Frequency } & $\begin{array}{c}\text { Frequency of main types } \\
\text { of arguments }\end{array}$ \\
\hline \multirow{5}{*}{1} & \multirow{2}{*}{$1 / \mathrm{A}$} & a) & 12 & $8 \%$ & \multirow{5}{*}{24} \\
\hline & & b) & 3 & $2 \%$ & \\
\hline & \multirow{2}{*}{$1 / \mathrm{B}$} & a) & 7 & $5 \%$ & \\
\hline & & b) & 6 & $4 \%$ & \\
\hline & \multicolumn{2}{|l|}{$1 / \mathrm{C}$} & 0 & & \\
\hline \multirow{6}{*}{2} & \multicolumn{2}{|l|}{$2 / \mathrm{A}$} & 1 & $1 \%$ & \multirow{6}{*}{2} \\
\hline & \multicolumn{2}{|l|}{$2 / \mathrm{B}$} & 0 & & \\
\hline & \multicolumn{2}{|l|}{$2 / \mathrm{C}$} & 2 & $1 \%$ & \\
\hline & \multicolumn{2}{|l|}{$2 / \mathrm{D}$} & 1 & $1 \%$ & \\
\hline & \multicolumn{2}{|l|}{$2 / \mathrm{E}$} & 1 & $1 \%$ & \\
\hline & \multicolumn{2}{|l|}{$2 / \mathrm{F}$} & 0 & & \\
\hline \multirow{9}{*}{3} & \multicolumn{2}{|l|}{$3 / \mathrm{A}$} & 28 & $18 \%$ & \multirow{9}{*}{30} \\
\hline & \multicolumn{2}{|l|}{$3 / \mathrm{B}$} & 0 & & \\
\hline & \multirow{3}{*}{$3 / C$} & a) & 30 & $20 \%$ & \\
\hline & & b) & 0 & & \\
\hline & & c) & 0 & & \\
\hline & \multirow{3}{*}{$3 / D$} & a) & 0 & & \\
\hline & & b) & 0 & & \\
\hline & & c) & 0 & & \\
\hline & $3 / \mathrm{E}$ & & 0 & & \\
\hline \multirow{4}{*}{4} & $4 / \mathrm{A}$ & & 12 & $8 \%$ & \multirow{4}{*}{30} \\
\hline & 4/B & & 30 & $20 \%$ & \\
\hline & \multicolumn{2}{|l|}{$4 / C$} & 1 & $1 \%$ & \\
\hline & \multicolumn{2}{|l|}{$4 / \mathrm{D}$} & 1 & $1 \%$ & \\
\hline 5 & & & 4 & $3 \%$ & 4 \\
\hline \multirow{4}{*}{6} & \multicolumn{2}{|l|}{$6 / \mathrm{A}$} & 2 & $1 \%$ & \multirow{4}{*}{3} \\
\hline & \multicolumn{2}{|l|}{$6 / \mathrm{B}$} & 0 & & \\
\hline & \multicolumn{2}{|l|}{$6 / \mathrm{C}$} & 2 & $1 \%$ & \\
\hline & $6 / D$ & & 0 & & \\
\hline 7 & & & 8 & $6 \%$ & 8 \\
\hline 8 & & & 4 & $2 \%$ & 4 \\
\hline 9 & & & 0 & & 0 \\
\hline
\end{tabular}


1. Grammatical (textual) interpretation

$1 / A$. Interpretation based on ordinary meaning

a) Semantic interpretation

b) Syntactic interpretation

1/B. Legal professional (dogmatic) interpretation

a) Simple conceptual dogmatic (doctrinal) interpretation (regarding either constitutional or other branches of law)

b) Interpretation on the basis of legal principles of statutes or branches of law

$1 / C$. Other professional interpretation (in accordance with a non-legal technical meaning)

2. Logical (linguistic-logical) arguments

2/A. Argumentum a minore ad maius: inference from smaller to bigger

$2 / B$. Argumentum a maiore ad minus: inference from bigger to smaller

2/C. Argumentum ad absurdum

2/D. Argumentum a contrario/arguments from silence

2/E. Argumentum a simili, including analogy

2/F. Interpretation according to other logical maxims

3. Domestic systemic arguments (systemic or harmonising arguments)

3/A. Contextual interpretation

a) In narrow sense

b) In broad sense (including 'derogatory formulae': lex superior derogat legi inferiori, lex specialis derogat legi generali, lex posterior derogat legi priori)

$3 / B$. Interpretation of constitutional norms on the basis of domestic statutory law (acts, decrees)

$3 / C$. Interpretation of fundamental rights on the basis of jurisprudence of the constitutional court

a) References to specific previous decisions of the constitutional court (as 'precedents')

b) Reference to the 'practice' of the constitutional court

c) References to abstract norms formed by the constitutional court

$3 / D$. Interpretation of fundamental rights on the basis of jurisprudence of ordinary courts

a) Interpretation referring to the practice of ordinary courts

b) Interpretation referring to individual court decisions

c) Interpretation referring to abstract judicial norms

3/E. Interpretation of fundamental rights on the basis of normative acts of other domestic state organs

4. External systemic and comparative law arguments

4/A. Interpretation of fundamental rights on the basis of international treaties

$4 / B$. Interpretation of fundamental rights on the basis of individual case decisions or jurisprudence of international fora

4/C. Comparative law arguments

a) References to concrete norms of a particular foreign legal system (constitution, statutes, decrees)

b) References to decisions of the constitutional court or ordinary court of a particular foreign legal system

c) General references to 'European practice', 'principles followed by democratic countries', and similar nonspecific justificatory principles

4/D. Other external sources of interpretation (e.g. customary international law, ius cogens)

5. Teleological/objective teleological interpretation (based on the objective and social purpose of the legislation)

6. Historical/subjective teleological interpretation (based on the intention of the legislator):

$6 / A$. Interpretation based on ministerial/proposer justification

$6 / B$. Interpretation based on draft materials

$6 / C$. Interpretation referring, in general, to the 'intention, will of the constitution-maker'

$6 / D$. Other interpretation based on the circumstances of making or modifying/amending the constitution or the constitutional provision (fundamental right) in question

7. Interpretation based on jurisprudence (references to scholarly works)

8. Interpretation in light of general legal principles (not expressed in statutes)

9. Substantive interpretation referring directly to generally accepted non-legal values 